\title{
Im/politeness, social practice and the participation order
}

\author{
Michael Haugh \\ School of Languages and Linguistics \\ Griffith University \\ Nathan, QLD 4111 \\ Australia \\ Phone: +61 7 3735-5150 \\ Email: m.haugh@griffith.edu.au
}

\begin{abstract}
$\mathrm{Im} /$ politeness is often conceptualised as the hearer's evaluation of a speaker's behaviour in discursive politeness research, representing the broader concern with the participant's perspective in current im/politeness research. Yet despite the importance afforded evaluations in such approaches, the notion of evaluation itself has remained, with just a few notable exceptions, remarkably under-theorised in pragmatics. In this paper it is proposed, building on work from discursive psychology and ethnomethodology, that im/politeness evaluations are intimately inter-related with the interactional achievement of social actions and pragmatic meanings vis-à-vis the moral order, and thus evaluations of im/politeness can be ultimately understood as a form of social practice. However, it is argued that an analysis of im/politeness as social practice necessitates a move away from a simplistic speaker-hearer model of interaction to a consideration of the broader participation framework (Goffman, 1981) within which they arise, and the positioning of the analysts vis-à-vis that participation order. A key finding from close analysis of evaluations of im/politeness in interaction relative to these participation footings is that they are distributed, variable and cumulative in nature.
\end{abstract}

\section{Keywords}

im/politeness, evaluation, social practice, moral order, participation framework, Conversation Analysis, Discursive Psychology, Ethnomethodology

\section{Bionotes}

Michael Haugh is an Associate Professor in Linguistics and International English in the School of Languages and Linguistics at Griffith University, Brisbane, Australia. His areas of research interest include face, im/politeness, humour, intention and implicature, drawing from both interactional and discursive perspectives. He has edited a number of journal special issues, including "Intention in pragmatics” for Intercultural Pragmatics (2008), "Conceptualisations of communication” for Australian Journal of Linguistics (2009), "Face in interaction” (2010) and "Im/politeness across Englishes" (2012) for Journal of Pragmatics, as well as coediting Face, Communication and Social Interaction (2009, Equinox) and Situated Politeness (2011, Continuum). He is also author of a number of forthcoming books, including Pragmatics and the English Language (Palgrave Macmillan, with Jonathan Culpeper), Understanding Politeness (Cambridge University Press, with Dániel Z. Kádár), and (Im)politeness Implicatures (Mouton de Gruyter). 


\section{Im/politeness, social practice and the participation order}

\section{Introduction}

One of the key claims to have emerged in im/politeness research in the past decade is that it is constituted not through linguistic or non-linguistic behaviour per se but through evaluations of such behaviour.

In everyday practice (im)politeness occurs not so much when the speaker produces behaviour but rather when the hearer evaluates that behaviour...the very essence of (im)politeness lies in this evaluative moment. Whether it involves hearers evaluating speakers, speakers evaluating themselves, or informants evaluating hypothetical speakers or utterances, the evaluative moment is always present. Indeed, in practice it proves to be the only way in which (im)politeness can be studied. Evaluation is thus the basic, primordial mode of being of (im)politeness. (Eelen, 2001: 109, emphasis added)

Im/politeness has thus been increasingly characterised as either an interpersonal attitude (Culpeper, 2011; Haugh, 2007a; Ruhi, 2008), or as an evaluation (Eelen, 2001; Haugh, 2007b; Locher and Watts, 2005; Mills, 2003; Spencer-Oatey, 2005; Watts, 2003). The so-called "discursive turn" in politeness research, for instance, has witnessed an attempt to engineer a paradigm shift in pragmatics, away from a focus on linguistic forms and strategies as "carriers" of im/politeness, to a view where $\mathrm{im} /$ politeness is theorised as evaluations that are situated within localised interactions (Eelen, 2001; Mills, 2003; Kádár and Mills, 2011; Locher and Watts, 2005; LPRG, 2011; Watts, 2003). This move has also been mirrored, at least to some extent, in other approaches to interpersonal dimensions of communication, such as Rapport management theory (Spencer-Oatey, [2000]2008, 2002, 2005) and Face Constituting theory (Arundale, 1999, 2006, 2010a, 2010b), where im/politeness is theorised as a form of interpersonal evaluation, albeit as just one element of a much larger relational tapestry.

Yet despite the attested importance of evaluations in the discursive approach to im/politeness, and indeed interpersonal pragmatics more broadly, the notion of evaluation has itself remained remarkably under-theorised in pragmatics, in marked contrast to the long history of theoretical work on pragmatic meaning and social actions (although see Mills [2003] for an important exception to this trend). While Eelen (2001), for instance, argued that im/politeness crucially involves evaluative moments, he did not offer any clear theorisation of such evaluations per se - albeit in part because the primary aim of his work was to offer a critique of previous theories of politeness. In this paper, it is argued that the relative neglect of how evaluations should be theorised vis-à-vis im/politeness has perpetuated a number of ongoing disputes in the field.

There is, for instance, considerable debate about the basis on which linguistic behaviour or conduct more generally is evaluated as polite, not polite, not impolite, impolite, mock impolite, mock polite, neither polite nor impolite, over-polite and so on. This question is often framed in terms of norms and facework. It is now generally accepted, however, that such norms are not something that participants "carry around" in their heads and apply unwittingly like "cultural dopes" (Garfinkel, 1967), a position which Eelen (2001) convincingly argued against in his critique of the first-wave of $\mathrm{im} /$ politeness research. Yet while there has been insightful research on the ideological 
underpinnings of such norms and how they are discursively constructed (Mills, 2003), there has been less attention paid to how these are asserted as norms in first place by participants themselves, as well as, consequently, by analysts (Mills, 2009). Notions such as habitus (Watts, 2003) or frames (Locher, 2004; cf. Terkourafi, 2005), and claims that norms can be discursively contested (Mills, 2003; Locher and Watts, 2008), arguably only tell us part of the story. In other words, although evaluations of $\mathrm{im} /$ politeness are traced back to an assessment made by either a participant or an analyst (in most cases relating to some kind of threat to or mitigation of that threat to 'face'), the actual grounds on which something is evaluated as im/polite in the first place are still left largely implicit in im/politeness research. It is simply asserted that something is polite, impolite, and so on because a participant (or the analyst) perceives or judges it to be im/polite, or because it is categorised as an instance of facework. The latter is arguably something that only analysts can attribute, however, given the notion of face employed is generally a technical one that is not necessarily recognisable to participants. But this approach to grounding evaluations of $\mathrm{im} /$ politeness begs the question, if we accept that facework does not necessarily always underpin such evaluations (Haugh and Bargiela-Chiappini, 2010; Haugh, 2013a; Mills, 2003; Watts, 2003; cf. Locher and Watts, 2005), then on what grounds can we make the claim that something be evaluated as im/polite in the first place?

There is also ongoing controversy as to the status of speaker intentions vis-àvis im/politeness. On the one hand, a number of scholars have argued that attributing intentions to speakers is a necessary condition for politeness (Brown and Levinson, 1987) or impoliteness/rudeness (Bousfield, 2008, 2010; Culpeper, 1996, 2005) to arise. On the other hand, others have argued that attributing intentions to speakers to be polite, impolite and so on is not constitutive of im/politeness (Culpeper 2011; Locher and Watts 2008; Mills 2003). The latter observe that while participants may implicitly or explicitly ascribe im/polite intentions to speakers, any attribution of an intention to be im/polite arises coordinate with an evaluation of im/politeness. In other words, while attributing im/polite intentions to speakers may (potentially) modulate the perceived degree of im/politeness, such intentions need not be attributed for evaluations of im/politeness to arise in the first place. ${ }^{1}$ One can claim, for instance, to have been, or be perceived to have been, unintentionally im/polite (Haugh, 2008, 2010a; Holmes, Marra and Schnurr, 2008; Mills, 2005). It has also been argued that $\mathrm{im} /$ politeness can arise, in some instances, through default evaluations that do not require recourse to inferences about the speaker's putative intentions (Terkourafi, 2005). However, if it is not what the speaker might be (taken to be) intending that determines whether something is polite, impolite, mock polite, over-polite and so on, then to whom can we trace such evaluations? The fact that this question has not yet been satisfactorily resolved has arguably led to ongoing debates about whether it is really the participants' perspective, or simply the analyst's perspective masquerading as the participants' perspective, which underpins many studies of im/politeness.

In this paper, it is thus first argued that one key issue that has been relatively neglected in im/politeness research is how participants (and thus analysts) know something counts as im/polite, im/proper, in/appropriate and so on. The underlying question here is what is the basis for claiming that something is polite, proper, appropriate, impolite, over-polite, inappropriate, an impropriety, a breach of etiquette

\footnotetext{
${ }^{1}$ The term "intention" has a wide range of meanings and usages in pragmatics (Haugh and Jaszczolt 2012). Here italics are used to indicate intention in the folk or discursive sense, that is, displays through interaction of what participants take to be the underlying aim, agenda or "project" of others (as well as themselves).
} 
and so on and so forth? It is proposed in this paper that to identify the grounds or warrants for evaluations of im/politeness requires careful consideration of how the interactional practices by which we understand each other are open to moral evaluation by participants due to the fact that such understandings, which constitute the "familiar scenes of everyday affairs", are familiar and taken-for-granted "because it is morally right or wrong that they are so" (Garfinkel, [1964]1967: 35, emphasis added). While such an approach, which is grounded in an ethnomethodological understanding of the moral order, echoes in some respects previous approaches that have appealed to the notion of social practice in theorising im/politeness (Eelen, 2001; Mills, 2003, 2009; Watts, 2003; cf. Garcés-Conejos Blitvich, 2013), the current proposal goes much further in suggesting that we need to treat evaluations of $\mathrm{im} /$ politeness not simply as arising in social practice, but to theorise im/politeness as a form of social practice in and of itself.

It is subsequently argued that a second key issue in im/politeness research is the question of just whose evaluations of im/politeness we are in fact analysing. In other words, im/polite, im/proper, in/appropriate and so on according to whom? While it is now generally accepted that we are dealing with the evaluations of participants in $\mathrm{im} /$ politeness research, the notion of participant itself has generally been relatively under-theorised, remaining largely at the level of undifferentiated speakers or hearers. This stands in stark contrast with the much more finely nuanced notions of participant and participation that have been developed in analyses of social action, for instance (e.g. Goffman, [1979]1981; Goodwin and Goodwin, 2004; Levinson, 1988). It is thus proposed that a treatment of politeness as social practice necessitates situating evaluations of politeness vis-à-vis the participation framework in interaction. This also has important implications for how we as analysts situate ourselves vis-à-vis this participation order.

This paper begins in the following section by first briefly reviewing prior work that has theorised im/politeness from a social practice perspective. In section three that follows, it is argued, building in part on Eelen's (2001) initial sketch, but also drawing from work in discursive psychology and ethnomethodology, that $\mathrm{im} /$ politeness not only arises in social practice, but is itself a form of social practice. However, in analysing im/politeness as social practice it is argued in section four that we need to go beyond a simplistic speaker-hearer model of communication to consider the broader participation framework (Goffman, [1979]1981) within which such evaluations arise, as it is only relative to these that their distributed, variable and cumulative nature can be understood. It is then briefly suggested in section five that the participation framework needs to be extended to interactions that are experienced vicariously through interactions mediated via various technologies, including popular media, social media and computer-mediated communications more broadly. It is relative to this broader participation order that we as analysts must also situate ourselves. The implications of the proposed account of im/politeness for debates around intentions and norms, as well as for studies in interpersonal pragmatics more broadly, are then briefly considered in the final section.

\section{Im/politeness and social practice}

Social practice is defined in various ways, but it essentially refers to the ways in which persons as social beings, as opposed to biological entities, are constituted through "embodied, materially mediated arrays of human activity centrally organized around shared practical understanding", which constitute a "field of practice" across 
groups, institutions, societies and so on (Schtazki, 2001: 11). The basic claim across various theories of practice is that "order is understood as (a) feature(s) of this field, and...components and aspects of that field are deemed responsible for the establishment of order" (ibid.: 14). In other words, social practices underpin both "regularities of behaviour or belief" (i.e. practices as regularities), as well as "arrays of activities that answer to norms of behaviour" (i.e. practice as normative) (Rouse, 2001: 198). Practice theories have their origins in work of philosophers (Bourdieu, 1977; Foucault, 1972), but have since been extended into various disciplines, including sociology (e.g. Gidden, 1984), anthropology (e.g. Ortner, 2006), and more recently (critical) discourse analysis (Fairclough, 2003; Pennycook 2010), all of which have influenced methods and theories in pragmatics more generally in various ways.

The claim that im/politeness should be theorised from a social practice perspective has its origins in a volume edited by Watts, Ide and Ehlich (1992), where the distinction between first-order politeness (that is, the participant's perspective) and second-order politeness (that is, the analyst's or theorist's perspective) was first proposed. $^{2}$ The notion of practice has subsequently been taken up in various "discursive" approaches to theorising im/politeness (Eelen, 2001; Mills, 2003; Locher, 2004, 2006; Watts, 2003). Eelen (2001) and Watts (2003), for instance, have both drawn from Bourdieu's $(1977,1990)$ theory of practice, in particular, the notion of "habitus", in their approaches to im/politeness. Eelen (2001) highlighted two key issues that a theory of im/politeness should orient towards, namely, the tension between variability and sharedness in evaluations of im/politeness, and the place of interpersonal power vis-à-vis im/politeness, including the argumentativity or contestedness in evaluations of im/politeness the latter gives rise to. As Eelen (2001) notes, there is a seeming contradiction between the variability in evaluations of $\mathrm{im} /$ politeness that is illustrated through empirical studies, and the assumption that evaluations of im/politeness must be somehow be "shared" across speakers. It is thus argued the notion of "habitus", which refers to "a set of dispositions to act in certain ways [that] generates cognitive and bodily practices in the individual" (Watts, 2003: 149), can be invoked to account for this apparent tension. The basic claim is that the "feel for the game" of an individual is "acquired through socialisation" (Watts, 2003: 149), which accounts for the "sharedness" in evaluations of im/politeness, but given we all have our own personal history of socialisation, this "feel for the game" is unlikely to be exactly the same across individuals, even if they identify themselves with the same social group(s), thereby accounting for variability (p.165). However, Watts (2003) takes the ideas of Bourdieu further than Eelen (2001) in arguing that politeness can be conceptualised as a form of "capital”, and so explicitly draws on the metaphor of "money" and "payment" in accounting for the links between evaluations of im/politeness, interpersonal power and argumentativity or contestedness (p.144). The link between evaluations of im/politeness and power, including class struggles, is also taken up by Mills (2003, 2009), who draws from Foucault's (1972) work in conceptualising politeness as a kind of "discourse". Im/politeness, on this view, involves indexing particular discourses, which can be rooted in communities of practice, but also in a society more broadly (Mills 2011a). These discourses can thus be drawn upon as a "resource" in interaction (Mills 2011b) in order to instantiate particular identities, including vis-à-vis claims to interpersonal power. Finally, the notion of practice has been conceptualised in terms of “frames” by Locher (2004),

\footnotetext{
${ }^{2}$ Although cf. Haugh (2012b) and Kádár and Haugh (in press 2013) for a more nuanced view of the first-second order distinction in im/politeness research.
} 
who argues that such frames, which are "structures of expectation based on past experience" (Tannen, 1993: 53), inform the negotiation of relationships in situated activities and practices (Locher, 2012: 10-11). Once again, frames are claimed to account for the tension between variability and sharedness in evaluations of $\mathrm{im} /$ politeness.

As Garcés-Conejos Blitvich (2013) has recently argued, however, discursive approaches to im/politeness have drawn primarily from the so-called "first-wave" practice theory (i.e. those of Bourdieu or Foucault), and so have neglected the critiques by subsequent "second-wave" practice theorists (Schatzki, 1996; Schatzki, Cetina and von Savigny, 2001; Reckwitz, 2002). One critique of Bourdieu's practice theory, for instance, has been that it lacks the "empirical specificity needed to assess his claims” (Hanks 2005: 69). Indeed, Eelen's (2001) framework is largely devoid of any concrete detail as to how the analyst might proceed. Watts (2003) and Locher (2004, 2006), in contrast, do attempt to flesh out their social practice framework through analyses of im/politeness in actual discourse, often drawing from metadiscursive comments or prosodic clues to ground their analyses, but ultimately are forced to retreat to generally only making claims that something is "open to evaluation" as polite, impolite and so on (e.g. Locher and Watts, 2005: 17; Locher, 2006: 263). However, while analytical equivocality is indeed understandable in particular instances where the participants themselves orient to such equivocality, such a position arguably undermines a claim to be doing analysis in the first place if it is consistently employed by im/politeness researchers (Haugh 2007b: 303-304). ${ }^{3}$ And while Mills (2003) fully acknowledges the difficulties that analysing data from a discursive perspective throws up, and so suggests that methods and approaches developed in conversation analysis and critical discourse analysis might be fruitfully employed, this has remained more of a suggestion than a worked-through proposal to date. The first problem is thus a methodological one. How do we as analysts confidently identify instances of im/politeness?

A second critique of first-wave practice theory that is of relevance to $\mathrm{im} /$ politeness researchers is the neglect of the ways in which social structures and instititutions (including arguably im/politeness) are "structured by the routines of social practice" (Reckwitz 2002: 255). In other words, the lack of detailed attention paid to the recurrent instantiation of social practices across on-going interlinked interactions through which these emergent relational systems are co-constituted in the first place (Haugh, 2012a). One key problem with relying on notions such as habitus and frames to provide such an account, at least according to Rawls (2003), is that they implicitly assume individuals are using "frames or typifications to locate orders of practice” (p.235, emphasis added). However, Rawls (2003) counters that "knowledge comes not from the application of concepts/typifications that we carry around with us, to situations, but rather from careful attention to witnessable aspects of ongoing performance or practice" and thus "order lies in the mastery of practices for reproducing situations, not in conceptual typifications for recognizing them” (p.255). In other words, approaches to im/politeness that draw from first-wave practice theory are not well positioned to explain how such practices vis-à-vis im/politeness are not only acquired by individuals, but also form emergent systems across relational or social networks, which can be perceived as regular, predictable and ordered in spite of

\footnotetext{
${ }^{3}$ It is worth noting that a metapragmatic approach, which includes but goes beyond examining metadiscursive comments by participants, offers at least some promise in this direction as well (e.g. Culpeper, 2011a; Haugh, 2010a, 2010c, 2013c; Kádár and Haugh in press 2013; cf. Locher and Watts, 2008), although exploring this lies possibility outside the scope of the current paper.
} 
the highly localised, situated and thus inherently unpredictable nature of interpersonal interaction. The second problem is thus primarily a theoretical one. How can we ground our analyses of im/politeness in claims that they are underpinned by "norms" or normative frames of reference when variability is inherent to evaluations of $\mathrm{im} /$ politeness? This issue reflects the broader question of just what are the grounds for claiming something is polite, not polite, not impolite, impolite, mock impolite, mock polite, neither polite nor impolite, over-polite and so on. To claim evaluations of $\mathrm{im} /$ politeness are a function of social norms is to implicitly reify such norms, as Eelen (2001) has argued, and so does not adequately address that fundamental question. In the following section it is proposed that while practice theory has indeed proved useful in spurring on the development of far-reaching critiques of earlier work and thus the beginnings of fresh approaches to im/politeness, what has been missed thus far is that evaluations of im/politeness do not simply arise in ongoing social practice, but are themselves a form of social practice. A social practice involves constituting persons and relationships through ongoing "arrays of activity". The focus in conceptualising im/politeness as social practice is thus on what participants are doing through evaluations of im/politeness, and how such evaluations are interdependently interlinked with the interactional achievement of social actions and meanings.

\section{Im/politeness as social practice and the moral order}

It is proposed in this section, building in particular on important insights offered in Eelen's (2001) and Mills' (2003) critiques of first-wave approaches to politeness, that in order to theorise evaluations in interaction we should first "look to natural talk or discourse to understand how evaluations are constructed and put together in everyday life” (Augoustinos, Walker and Donaghue 2006: 140), and thereby better understand "what is done with evaluations" (Potter, 1998: 242, original emphasis). ${ }^{4}$ Consistent with what is argued by discursive psychologists, who draw, in turn, on work in conversation analysis on assessments (e.g. Goodwin and Goodwin, 1987; Pomerantz, 1984), it is suggested that im/politeness be conceptualised first and foremost as a form of "evaluative practice", which is occasioned through talk that performs particular "social actions in specific interactional settings" (Augoustinos, Walker and Donaghue, 2006: 145). However, their line of work is extended here to evaluations occasioned through the pragmatic meanings that arise coordinate with social actions in specific interactional settings, since participants are not only taken to be doing things through talk-in-interaction (i.e., social actions), as often emphasised by conversation analysts (Schegloff, 1995), they are also meaning things (i.e., pragmatic meanings), since such actions must necessarily have an object, that is, they must be about something. A request, for instance, is recognisable as social action because it arises through recognisable practices for formulating turns at talk (e.g. I was wondering if you could...), and because subsequent responses to that talk display in themselves recognition of that prior action (e.g. granting or declining) (Heritage, 1984a; Schegloff, 2007). However, a request is also recognisable because it has an object, that is, it is a request about something. The object of a social action generally involves meaning representation(s), the content of which is not only represented as part of what is said, but can also be represented as implicatures (Haugh, forthcoming), or other kinds of pragmatic meaning.

\footnotetext{
${ }^{4}$ Parts of this section are summarised in Chapter Four of Kádár and Haugh (in press 2013).
} 
One of main foci for analysts in theorising im/politeness as social practice, then, is on the "resources for constructing evaluations", including "categories, commonplaces, interpretative repertoires” (Potter, 1998: 259). An important consequence of conceptualising evaluations in this way is that it becomes apparent that other kinds of social action, such as assessing and complimenting (Goodwin and Goodwin, 1987; Pomerantz, 1978a, 1984), complaining (e.g. Drew 1998; Drew and Walker, 2009), accusing and blaming (e.g. Pomerantz 1978b) and criticising, 'teasing' (e.g. Drew, 1987), and even questioning (e.g. Antaki, 2012; Stivers, Mondada and Steensig, 2011) are also inherently evaluative. Moreover, pragmatic meanings such as irony and sarcasm are also fundamentally evaluative in nature (Clift, 1999), a point originally noted some time ago by Grice (1978). Careful examination of how evaluative social actions and pragmatic meanings are interactionally achieved by participants is thus critical to the analysis of evaluations of im/politeness in interaction.

A further key insight from discursive psychology in relation to conceptualising $\mathrm{im} /$ politeness as social practice is that evaluations are not always consistent across individuals from the same "social group" (as defined by traditional sociolinguistic variables), or even within the same individual over time. Variability in interpersonal evaluations is to be expected and should be theorised as such because, as Potter (1998) argues,

evaluations are flexibly constructed to mesh with specific ongoing practices. Variation is expected as people perform different actions with their talk; for example, as they respond to assessments, align themselves with friends and differentiate themselves from enemies, and as they construct locally coherent versions of the social and moral world. (Potter, 1998: 244)

The inherent variability of evaluations of im/politeness when examined in interaction is muted, however, by analytical approaches that cast particular utterances or sequences as polite, impolite and so on, rather than focusing on how the participants themselves are evaluating social actions and pragmatic meanings vis-à-vis their interpersonal implications.

Such work raises the question, however, as to why social actions and pragmatic meanings are open to evaluation in this way. While discursive psychology itself does not directly address such issues, the longstanding tradition of ethnomethodology (Garfinkel, 1967; Heritage, 1984a), on which conversation analysis and discursive psychology both build, arguably does offer some insight into this question. ${ }^{5}$ In ethnomethodology, the focus is on the procedures and practices by which members make sense of everyday situated activities, and the ways in which members are held accountable for the emergence of such understandings (where "member" refers to a person who is recognised as affiliated with a particular social or relational network by other persons in that network). Critically, it is claimed that such procedures and practices are morally organised (Jayuusi, 1984, 1991), and so "practical activities (e.g. asking questions, providing descriptions and making 'sense') are also inexorably moral” (Housley and Fitzgerald, 2009: 347). Garfinkel ([1964]1967) terms this the "moral order", that is, the "take for granted" or " "seen but

\footnotetext{
${ }^{5}$ Wilson (2012) claims that, strictly speaking, conversation analysis builds on what he terms "classical ethnomethodology", the ideas of which are mostly presented in Garfinkel (1967) and summarised by Heritage (1984a), rather than in the "radical program" that constituted the focus of Garfinkel's (2002) later body of work.
} 
unnoticed', expected, background features of everyday scenes” (pp.35-36). ${ }^{6}$ However, this background to interpretation and evaluation is not just a matter of common knowledge, but is itself "inexorably moral”. This is because "for members not only are matters so about familiar scenes but they are so because it is morally right or wrong that they are so" ([1964]1967: 35, emphasis added). Critically, the "seen but unnoticed" expectations that constitute that moral order are also both "socially standardised and standardising” (p.36). This means they are not simply norms that somehow afford or constrain the behaviour of members, but rather are the means by which one makes a claim to be a member of society in the first place. In other words, not only do practices depend on these expectations in order to be recognisable to members, and thus accessible as interpretative resources, but also as members continually engage in such practices in their everyday interactions, they both sustain the moral order, and over time act to change it. The "seen but unnoticed" expectations of the moral order are thus not something to be simply assumed by the analyst, but rather constitute an important object of study in their own right.

One aspect of the moral order that has received close study in conversation analysis is what Heritage has termed the "epistemic order" (Heritage, 2012), which essentially refers to what participants "know relative to others, what they are entitled to know, and what they are entitled to describe or communicate" (Heritage, 2009: 309), and thus also encompasses "epistemic authority over knowledge and differential rights and responsibilities with respect to knowledge" (Stivers, Mondada and Steensig, 2011: 3). Recent work has demonstrated that the interactional negotiation of epistemic authority and epistemic gradients (i.e. how participants are positioned in relation to what they know or are entitled to know or describe vis-à-vis others) can be oriented to by participants as interactionally “delicate” (Sidnell, 2012; Stivers, 2011). Another aspect of the moral order that has also received attention recently is what Stevanovic and Peräkylä (2012) term the “deontic order”, which refers to what participants think is "obligatory, permissible, or forbidden” (p.299), and thus also encompasses "deontic authority" concerning "rights and obligations" (p.298). Curl and Drew (2008), for instance, identify (relational) "entitlements” as a key element of the deontic order that is oriented to by participants alongside contingencies in formulating directives and requests (see also Heinemann, 2006). The moral order is, however, "multi-faceted and multi-layered", as Haugh (2013b: 48) points out, and so the epistemic and deontic domains are just facets of "a much larger and richer tapestry” (p.48), the workings of which remain an important domain for ongoing research.

A key claim, then, in theorising im/politeness as social practice is that the moral order is what grounds our evaluations of social actions and meanings as "good" or "bad", "normal” or "exceptional”, "appropriate” or "inappropriate” and so on, and of course, as "polite", "impolite", "over-polite” and so on. ${ }^{7}$ Conceptualising $\mathrm{im} /$ politeness as social practice thus builds on the claim that social actions and pragmatic meanings are not simply the means and basis for accomplishing the multitude of interactions through which we constitute our daily lives, they are also "inexorably moral". They can thus also be interpreted in localised talk-in-interaction as evaluative of persons and/or relationships. A person here is conceptualised as an

\footnotetext{
${ }^{6}$ Goffman (1967) also emphasised the moral underpinnings of interpersonal interaction, drawing as he did from Durkheim's (1912) work on rituals, but he differed in critical ways in his approach to studying these (see Rawls, 2003, for further discussion).

${ }^{7}$ cf. Samra-Fredericks (2010) on the moral underpinnings of "face" from an ethnomethodological perspective.
} 
individual in a social environment, namely, the individual construed as a social being linked with others in social interaction, rather than as biological or psychological being (Haugh, 2013a), consistent with social practice theory, and echoing early work in symbolic interactionalism (Mead, 1934). In contrast, a relationship, following Arundale (2010b), is conceptualised as the "establishing and maintaining of connection between two otherwise separate individuals” (p.138). ${ }^{8}$ For example, a request involves an implicit assessment of the entitlements of the speaker (and thus involves an evaluation of his/her person) to make that request in that particular situated context (Curl and Drew, 2008). However, these entitlements are constituted relative to an (implicit) assessment of his/her (ongoing) relationship with the requestee. Jocular mockery (a form of non-serious teasing) involves not only an assessment of the person of the target (who is either an individual or group of individuals), but also an assessment of the relational connection between the speaker and the target (Haugh, 2010b; Haugh and Bousfield, 2012). Evaluations of $\mathrm{im} /$ politeness themselves are constituted through such implicit and explicit assessments of persons and relationships. ${ }^{9}$ To conceptualise im/politeness as social practice thus means examining evaluations as they are recognisably occasioned by social actions and meanings.

However, not only are im/politeness evaluations (co-)constituted through interaction in this way, they may also themselves reflexively occasion evaluative social actions/pragmatic meanings. Formulating a complainable leading to a complaint, for instance, is occasioned by an evaluation of some event as an "impropriety" that is attributed to the actions of an agentive individual (or group of individuals) (Drew, 1998, Pomerantz, 1978b). In other words, a social action, namely, formulating a complainable, arises due to an assessment of a person or group of persons as acting "improperly" or "inappropriately", and leads to a complaint about the event so formulated. A complaint also implicitly carries with it expectations about how those listening to the complaint will respond to it, and so has implications for the co-constitution of their ongoing relationship. In this sense, then, im/politeness evaluations are also potentially constitutive of interaction.

In the following interaction, three friends, Bob, Lisa and Tom are talking while playing computer games and studying. The excerpt here begins when Lisa starts offering an account for why she does not want to pick up Edna to take her to church that week. ${ }^{10}$

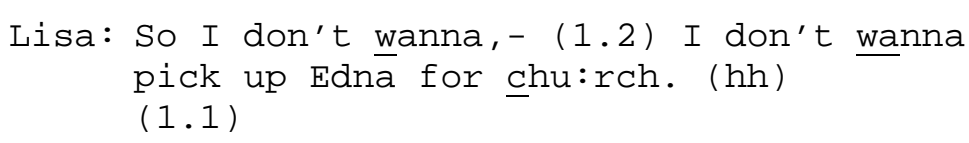

\footnotetext{
${ }^{8}$ I deliberately avoid the terms identity or face here as these are used in various different, and arguably theoretically incompatible, ways in the literature. From the perspective of Face Constituting Theory (Arundale, 2006, 2010a, this issue), identities are closely related to construals of persons, while face is intimately related to construals of relationships in interaction. However, given face is understood in other ways that align more closely with identities (e.g. Spencer-Oatey, 2007, this issue; Locher, 2008), the (currently) less "loaded" terms persons and relationships are utilised here to avoid definitional or theoretical confusion (see Haugh [2013] and Garcés-Conejos Blitvich [2013] for further discussion). ${ }^{9}$ cf. Garcés-Conejos Blitvich (2013: 18) who grounds evaluations of im/politeness in identity verification or non-verification, and recognition or threats to the authenticity/self-worth/self-efficacy attributes associated with that identity.

${ }^{10}$ The example here, and those that follow, have been transcribed following standard CA transcription conventions (Jefferson, 2004). See the list of transcription conventions at the end of this paper for further details. Thanks to Toby Richards for permission to use this excerpt.
} 


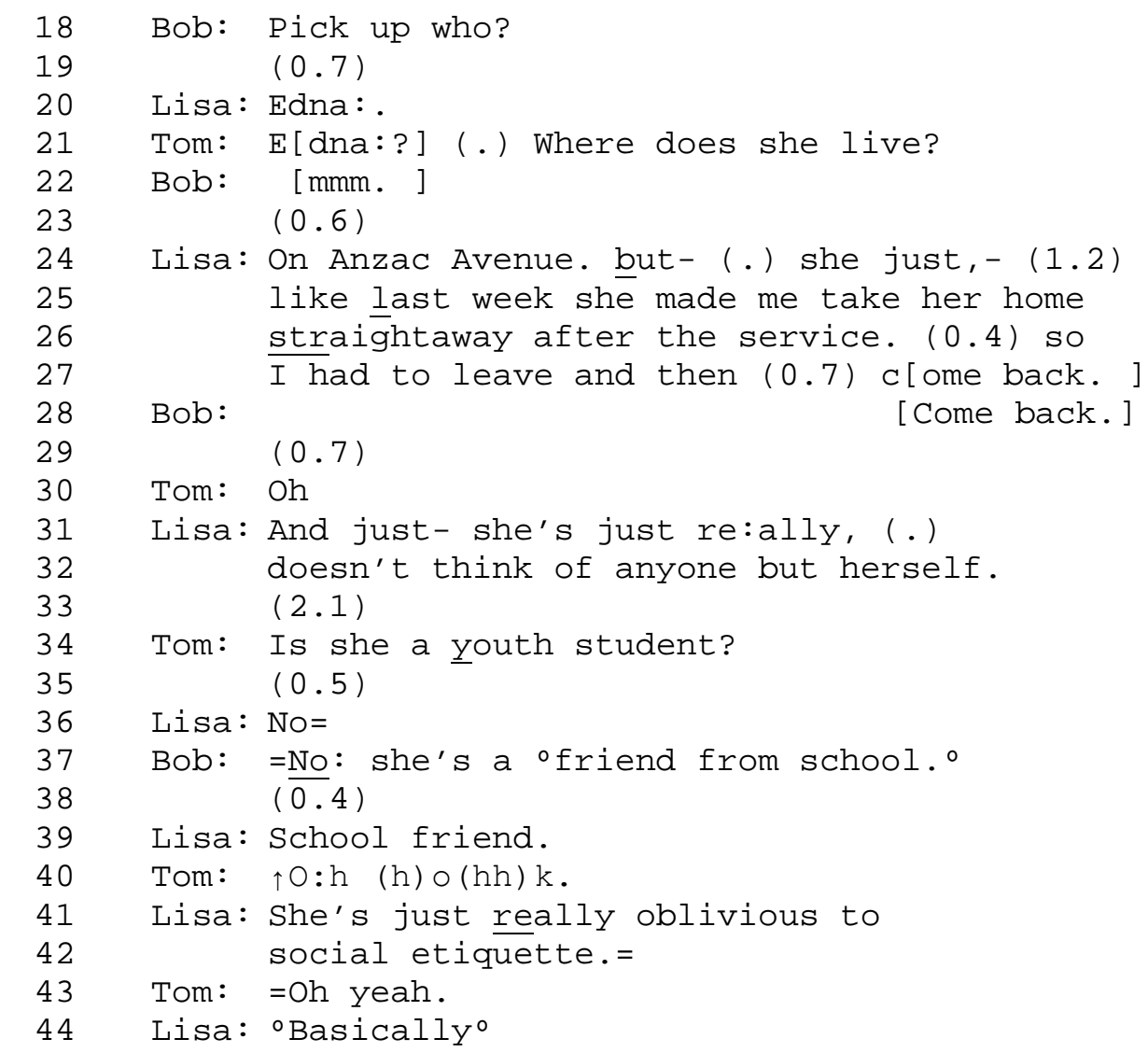

After clarifying the person being referred to and where she lives (lines 18-24), Lisa formulates a complainable, that is, a matter about which a complaint can be made, namely, that Edna asked Lisa to take her home straightaway, thereby forcing Lisa to make an extra trip (lines 24-27). Having formulated this extra trip as a complainable, Lisa then makes a recognisable complaint (i.e., that she "doesn't think of anyone but herself”) by implying that Edna does not think of others, or more specifically, does not show consideration for others (lines 31-32). What is notable about this complaint is that it is formulated at a more generalised level than the locally situated context of the complainable. In other words, it is not just on this occasion but possibly many times, if not all the time, that Edna lacks consideration for others. In being formulated in this way, Lisa invokes an aspect of the moral order, namely, the understanding that "not thinking of anyone but oneself" is a bad thing, and "people" (including the other participants present, as well as Edna) should know this. Lisa subsequently categorises this impropriety as a breach of "social etiquette" in casting Edna as someone who is "really oblivious to social etiquette", which thus constitutes a negative assessment of her person (lines 41-42). This complaint and assessment sequence is thus what Garfinkel (1956) referred to as a "public denunciation", which builds, in turn, on claims of "moral indignation". Notably, however, while the other participants do not strongly align with Lisa's complaint here by making some kind of assessment subsequent to it (cf. lines 34-40), and nor do they affiliate with her stance that Edna's behaviour constitutes an impropriety that reflects her lack of understanding of "social etiquette" (cf. line 43), they do not challenge it either. ${ }^{11}$ In other words, it is tacitly

\footnotetext{
${ }^{11}$ Following Stivers (2008), participants can align or disalign with a prior action in next turns, while they can also affiliate or disaffiliate with the stance (including interpersonal evaluations) that this social action occasions. The distinction between alignment and affiliation is important because while participants might align with a complaint by displaying recognition of a complainable as a complaint,
} 
accepted by Tom and Bob as consistent with their understandings of the underlying taken-for-granted moral expectancies to which Lisa's complaint appeals.

Through this example, we can observe three important characteristics of $\mathrm{im} /$ politeness as social practice. First, a negative assessment of Edna's person (i.e. as someone who is "inconsiderate" and "oblivious to social etiquette") is interactionally achieved through a complainable that subsequently develops into a complaint. This negative assessment of Edna also has implications for the relationship between Lisa, Bob and Tom, in that the degree to which they affiliate with Lisa's stance here has implications for their ongoing co-constituting of relational connection (or separation) with each other, or what can also be termed locally instantiated relational "coalitions" (cf. Dobs and Garcés-Conejos Blitvich, forthcoming). These evaluations are thus ultimately occasioned by particular social actions/meanings that are interactionally achieved in locally situated talk-in-interaction, and in this sense are (co-)constituted through interaction.

Second, we can observe an instance of a social action (i.e., a complaint) and meaning (i.e., the object of that complaint) being occasioned by a prior evaluation of someone else's conduct, namely, the perceived breach of social etiquette arising from Edna asking Lisa to drive her home straight after church. In other words, evaluating someone as im/polite can occasion subsequent social actions (e.g. a complaint).

Third, and most importantly, Lisa's negative assessment of Edna's person is not framed as an idiosyncratic evaluation, but rather one that is rooted in the moral order. In this case, Lisa's negative assessment is oriented to aspects of the deontic order, namely, her perception that Edna is positioning herself as entitled to make such a request in that particular situated context (and by implication others), and not orienting to the contingencies of the situation (i.e. Lisa wanting to stay after the service). It is this orientation to an unwarranted display of entitlement and neglect of appropriate contingencies, then, that grounds Lisa's claim that Edna's prior conduct constitutes an "impropriety", and so occasions her negative evaluation of Edna as "oblivious to social etiquette".

To theorise im/politeness as social practice thus means, on the one hand, to closely focus on how such evaluations are (reflexively) occasioned by social actions and meanings, which are recognisable to participants because of the ways they draw on interactional practices, that is, ways of formulating talk and conduct that are understood by participants as doing and meaning certain things. To be reflexively occasioned means that evaluations of im/politeness themselves also have the potential to occasion evaluative social actions and meanings (e.g. evaluating someone as impolite can occasion a complaint or negative assessment). On the other hand, evaluations of im/politeness involve implicit appeals to the moral order, which is constituted through practices by which social actions and meanings are made recognisable as "familiar scenes of everyday affairs", and so are open to moral evaluation (that is, as good/bad, appropriate/inappropriate, polite/not polite, impolite/not impolite and so on). Yet in implicitly involving an appeal to the moral order, and the practices that give rise to it, evaluations of politeness are thereby open to dispute, because members who identify with different groups, or even members who identify the same group, do not necessarily always constitute the moral order in the same way, given the moral order is not only constituted, but also open to change, by its members. This view of im/politeness as social practice is summarised in Figure 1 .

for instance, they may not necessarily affiliate with the stance of the initiator of that complaint (e.g. they may disagree, and thus disaffiliate, with the speaker's negative assessment). 


\section{[Insert Figure 1 about here]}

In relation to im/politeness, then, it is suggested here that evaluations of $\mathrm{im} /$ politeness by participants are occasioned through particular social actions and pragmatic meanings which are perceived to be evaluative of persons and/or relationships. More specifically, the evaluations of persons and/or relationships interactionally achieved through social actions/pragmatic meanings can occasion evaluations of those evaluations (of persons and/or relationships) as polite, impolite, not polite, not impolite, mock impolite, mock polite, neither polite nor impolite and so on and so forth. ${ }^{12}$ In the case of Edna, an assessment of her person as someone who "doesn't think of anyone but herself" is subsequently evaluated as indicative of her being "oblivious to social etiquette" (i.e., not considerate towards Lisa's perceived entitlements in the context of her relationship with Edna), and thus not polite or even impolite. Of course, evaluations of im/politeness are dependent on the formulation of the social actions/pragmatic meanings that ultimately occasion them, including the manner in which they are sequentially accomplished. This reflects, in part, the view of im/politeness as the "hearer's evaluation" advocated by discursive politeness theorists. However, conceptualising im/politeness as social practice is broader in scope and more nuanced in that it includes not only the evaluations of "hearers" (or even "speakers"), but of all of the participants in a particular interaction (and potentially meta-participants as well in some cases), as will be argued in the subsequent section.

It is also suggested, on this approach, that particular social actions and pragmatic meanings can be understood as reflexively evaluative of persons and/or relationships. In other words, certain social actions/pragmatic meanings can be occasioned by an individual's (or group of individuals') evaluation of a prior social action/pragmatic meaning as polite, impolite and so on. Social actions and meanings can thus themselves be occasioned by evaluations of im/politeness, and then subsequently occasion further (co-)constituted evaluations, as outlined above. In other words, evaluations of politeness, impoliteness and so on can at times be constitutive of interaction, when such evaluations occasion particular social actions (e.g. complaining, negative assessments and so on). This reflects, in part, the view of $\mathrm{im} /$ politeness as an attitude that can be "activated" by "particular-in-contextbehaviours" (Culpeper, 2011: 23). In other words, such attitudes do not necessarily arise de novo in particular interactions, but are themselves a constitutive force in talkin-interaction carrying over from prior interactions across emergent relational networks (Haugh, 2011; Haugh, Davies and Merrison, 2011; Mills, 2003; see also Kádár and Haugh, in press 2013). Evaluations of im/politeness, are therefore both (co)constituted in, and constitutive of, talk-in-interaction. It is in these ways, then, that $\mathrm{im} /$ politeness can be understood as a form of social practice.

Theorising im/politeness as social practice arguably moves us closer to answering one of the key questions in im/politeness research, namely, what are the grounds for evaluating something as polite, impolite and so on? In such an approach the focus is on how participants hold others and themselves accountable to the moral order. However, not only are participants held normatively accountable to the interactional order (Heritage, 1984, 1988), but they are also held morally accountable to the moral order, that is, accountable for the real-world consequences of what are

\footnotetext{
12 The array of possible im/politeness evaluators is, of course, subject to language/culture-specific nuances (see Kádár and Haugh, in press 2013).
} 
taken to be saying and doing. Given im/politeness evaluations are grounded in the accountability of social actions and pragmatic meanings vis-à-vis the moral order, the analysis of im/politeness evaluations necessarily requires close attention by analysts to the ways in which participants (implicitly) invoke aspects of the moral order in interaction. The moral order is thus in and of itself also a critical point of investigation for im/politeness researchers.

In treating evaluations of im/politeness as a social practice, then, the point being emphasised is that we do not think something or someone is polite, impolite and so on because of a particular behaviour on their part, or because they have used a particular linguistic form per se. Instead, it is because we evaluate the social action or meaning we interpret as arising through this (embodied) talk and conduct as evaluative of persons and/or relationships, and thus polite, impolite and so on. The content of these evaluations, and the social actions and meanings through which they arise (and they themselves give rise to), should thus be the starting point for empirical studies of im/politeness and interpersonal evaluations more generally in pragmatics. This entails, in turn, a move to more detailed examination of talk-in-interaction that is afforded by, although certainly not exclusively, by conversation analysis, for instance. However, in moving to link the analysis of evaluations of im/politeness to the interactional achievement of social actions and meanings, the perspectives of all participants in the interaction in question have necessarily been foregrounded, not just that of the speaker or hearer. In the following section, it is thus argued that we need to consider more carefully the ways in which these evaluations arise within particular, locally instantiated participation orders, namely, the systematic, principled arrays of normative expectancies that underpin the various participation footings that can arise through talk-in-interaction.

\section{Grounding evaluations of im/politeness in the participation order}

One of the most significant developments in im/politeness research has been the shift away from a singular focus on the speaker's behaviour or intentions. It has been argued that the evaluations of both speakers and hearers are critical in analysing im/politeness (Locher, 2004, 2006; Xie, 2008). Eelen (2001) goes even further in arguing that the "whole dyad becomes the focus of attention" in an evaluation-centred approach (p.110), and so im/politeness should be examined "as a truly social interactional phenomena located in both positions and in neither of them at the same time” (p.120). Haugh (2007b) has thus suggested a tripartite framework for analysis of im/politeness where we investigate not only the way in which im/politeness evaluations are projected by speakers (expressive politeness1) and interpreted by hearers (classificatory politeness1), but also "the interactional achievement of both converging and diverging evaluations of (im)politeness1” (p.307). While keeping these perspectives distinct in worked analyses of im/politeness in interaction can be challenging in of itself (cf. Dynel, 2012: 163), there is also a related problem in the eyes of some researchers at least as to whether we should be treating the hearer's evaluation or the speaker's intention vis-à-vis im/politeness as primary. The former tends to be the main, although not exclusive, focus of those who profess to adhere to "first-order" or discursive approaches to im/politeness (e.g. Eelen, 2001; Kádár and Mills, 2011; Locher and Watts, 2005; Mills, 2003), while the latter is strongly favoured by those researchers adhering to "second order" approaches (e.g. Bousfield, 2008, 2010; Terkourafi, 2005, 2008). I would suggest the most obvious answer is in fact neither: both speakers and hearers have their own distinct and often independent 
interests in regards to how they evaluate talk and conduct. Yet the question is useful if we start to consider more carefully the issue of just whose evaluations in interaction are we analysing. If we undertake close analysis of how interpersonal evaluations arise in interaction it becomes apparent, as we shall see, that we need to analyse much more carefully the footings and roles of all participants, going beyond a general speaker-hearer model of interaction (Haugh, Davies and Merrison, 2011; cf. Bousfield, 2008: 174-175; Dobs and Garcés-Conejos Blitvich, forthcoming; Dynel, 2012). The fundamental question in the analysis of im/politeness evaluations in interaction should therefore not just be whether some talk or conduct is im/polite, im/proper, in/appropriate and so on, but rather for whom is this polite, impolite and so on?

Such an argument is foreshadowed in Goffman's ([1979]1981) seminal claim that we need to deconstruct the "folk categories" of speaker and hearer into "smaller, analytically coherent elements” (p.129). There are two key elements of Goffman's proposals in relation to decomposing the categories of speaker and hearer. First, he suggested that the folk notion of speaker conflates four distinct sets of roles and responsibilities, or what he termed "footings". According to Goffman there are four different speaker footings: animator, author, principal and figure. An animator (or utterer) is the one producing talk, an author is the entity that creates or designs the talk, a principal is the party responsible for that talk, and a figure is the character portrayed within the talk. Second, he argued that the participation status of hearers is also much complex than assumed in folk models of communication. He proposed a set of participation statuses based on the intuitive distinction that we can make between hearing and listening, where the latter entails some kind of responsibility to attend to or participate in the talk. A ratified recipient (or participant) is an individual who is expected not only to hear, but also to listen to the talk. An unratified recipient (or non-participant), on the other hand, is an individual who can hear the talk, but is not necessarily expected to listen. These two types of recipients were further subdivided into different participation statuses. A ratified recipient may either be an addressee or an unaddressed side participant. An addressee is a person (or persons) to whom the utterance is (ostensibly) directed, but both addressees and side participants have recognised entitlements to respond to the utterance, although their degree of responsibility to do so varies (at least ostensibly). Unratified recipients, or nonparticipants, on the other hand, can be divided, following Verschueren (1999: 82-86), into bystanders and overhearers. The former encompasses an individual (or group of individuals) that can be expected to be able to hear at least some parts of the talk, but are not ratified as a participant. An overhearer, on the other hand, refers to an individual (or group of individuals) that might be able to hear some parts of the talk. Overhearers include listener-ins, that is, persons whom speakers and other ratified participants are aware can hear the talk, and eavesdroppers, that is, persons who are secretly following the talk. As Hatfield and Hahn (2011) point out, the presence of bystanders or even overhearers can be consequential for the way in which a particular social action (e.g. an apology) is evaluated as polite or impolite by those participants.

While there have been various reworkings of Goffman's basic proposals (cf. Dynel, 2011a, 2011b, 2012; Levinson, 1988; Verschueren, 1999), the most telling problem with Goffman's basic framework in relation to the analysis of the participation order underlying interpersonal evaluations in interaction is that

there is a marked asymmetry in the analytic frameworks used to describe different kinds of actors. The speaker is endowed with rich cognitive and linguistic capabilities, 
and the ability to take a reflexive stance toward the talk in progress. However, all other participants are left cognitively and linguistically simple. (Goodwin and Goodwin, 2004: 225)

The notion of speaker (or production) footing thus arguably needs to be complemented by the notion of recipient (or reception) footing. It is proposed here, therefore, that the animator (or producer) who engenders the talk (and conduct) has a counterpart in the various recipients (potentially) attending to that talk or conduct. ${ }^{13}$ The role of the author who constructs the talk has a counterpart in the interpreter or interpreters who can develop their own understandings of the talk. The role of the principal who is socially responsible for those meanings or actions is necessarily complemented by the accounter or accounters who (explicitly or tacitly) hold the principal responsible. And, finally, the production role of figure, namely, the character that is depicted in the talk, is also a potential target when the character depicted is copresent, or when an utterance is attributed to someone other than the speaker.

The complex array of participation footings proposed here are summarised in Figure 2 below.

\section{[Insert Figure 2 about here]}

From this figure it is apparent that interpersonal evaluations, including evaluations of $\mathrm{im} /$ politeness, need to be situated vis-à-vis not only simply speakers or hearers, but also relative to a complex array of production and reception footings, the coconstitution of which is itself and morally implicative activity in interaction.

The importance of these multiple participation footings to the analysis of evaluations of im/politeness can be illustrated through an examination of the following excerpt from a conversation after lunch between four family members in a suburban home in Australia. Melissa has given an unusual present to Cindy and Bryan. They have been trying to guess what it is along with Tim. This, in turn, occasions a joint evaluative activity where the others are implicitly invited to comment on the gift. However, rather than responding with positive assessments, as might be expected (Good and Beach, 2005; Robles, 2012), this joint evaluative activity has quickly morphed into a teasing sequence, where Bryan and Tim have begun casting the present as an object of derision open to being mocked or "knocked". ${ }^{14}$ The excerpt below begins when Melissa attempts to offer an account for the unsophisticated nature of the present by formulating it as something that cost "only three dollars". However, this account does not affect the trajectory of this teasing sequence which continues on, as can be seen below.

(2) GCSAusE03: 1:29

$66 \mathrm{M}: \quad$ it was only $\downarrow$ three dollars so I thought $0:: \mathrm{h}=$

67 B: =I mean, is that a crap paint job? or is it-

68 is that art[istic.]

69 M: $[0, h h$,$] I just pulled the (.) price$

70 tag off it.

71 T: it looks like [it's been done-]

72 B: [No: I'm talking] about the

\footnotetext{
${ }^{13}$ It is in making this extension that the current approach most obviously contrasts with that of other recent proposals in relation to the participation framework and im/politeness evaluations.

${ }^{14}$ This kind of jocular mockery has been found to be a recurrent practice in Anglo-Australian interpersonal interactions (Béal and Mullan, forthcoming; Haugh, 2010b, 2011b).
} 
T: $\quad[0: h$ right. $]$

B: =were holding it.

M: $\quad[0:::$ h. $]$

T: $\quad$ it looks] like it $w^{\prime} s$ done with a pen.

B: does it?

(. )

T: yeah it [looks-

M: $\quad[\uparrow 0:: H$, I didn't notice that?

B: it looks like Joanna's painted it.

C: .hhh $\mathrm{He}[$ hehe]

M: $\quad\left[{ }^{\circ}\right.$ no, $]$ I didn't notice that. ${ }^{\circ}$

Bryan implies a negative assessment of the present (which is apparently a mosquito coil holder) in formulating an alternative question (i.e. "a crap paint job” or "artistic"?) in lines 67-68. In taking the form of an alternative question, Bryan seemingly increases the epistemic gradient in favour of the direct addressee, Melissa, thereby, on the surface at least, assigning greater epistemic authority to her (Stivers, 2010). In other words, in offering two alternatives rather than presupposing a candidate answer through a polar question (Pomerantz, 1988), Bryan appears to be signalling that Melissa is more knowledgeable than him in regards to the item being assessed here (i.e. the epistemic gradient inclined even more in her favour), and so has greater rights to evaluating it than him (i.e. has greater epistemic authority). However, because the latter option ("is that artistic") is meant only ostensibly in that it is clearly an ironic alternative of which Bryan is the producer but not the principal, in practice Bryan in fact asserts epistemic authority over Melissa through this ironic formulation. Thus, not only does Bryan criticise the present by finding fault with its appearance (i.e., it has a "crap paint job”), he also achieves a concurrent shift in speaker footing through the irony (Clift, 1999), whereby he detaches himself from commitment as principal of that second alternative (i.e., a positive assessment of the object as "artistic"), to a mocking evaluation of that assessment (i.e., something like "what kind of person would consider this artistic?”). This proves critical as through this ironic evaluation, Bryan implies a negative assessment of not only the object itself but also Melissa herself for purchasing the present in the first place. Through this footing shift Bryan also implicitly invites the side participants here (Cindy and Tim) to share this ironic perspective (Clift, 1999). That this utterance is treated as implying a negative assessment rather than being understood as a straightforward information-seeking question is apparent from Melissa's response in lines 69-70, where she offers an account for the "crap paint job”. That the latter alternative is treated as an ironically achieved negative assessment, where the others are invited to share this mocking perspective, is apparent from Tim's subsequent initial formulation of a tease in line 71 that attempts to further this overall teasing project.

However, at this point, Bryan interrupts Tim, moving to reject this account from Melissa by explicitly repairing Melissa's just prior displayed understanding of his negative assessment. Specifically, he claims that he was referring to the paint job of the present in general, not just where the price tag was ripped off (lines 72-73). He goes on to further criticise the present by pointing out there are areas where the paint job is incomplete (lines 73-77, 79). This repaired understanding is oriented to as 
"new” information by Melissa through the "oh" particle (Heritage, 1984b), followed by an "okay" through which Melissa displays acceptance of the stance embodied in Bryan's response (Beach, 1995; Schegloff, 2007), namely, his claim that the paint job in general is not very good. It is also worth noting, that up to this point in the sequence, then, it is primarily Melissa and Bryan who have been taking the reception footings of "accounter" in holding each other interactionally accountable to particular social actions and pragmatic meanings through understandings displayed in subsequent turns, while all five interactants have taken the reception footings of interpreters and ratified recipients (either as addressees or side participants).

At this point, Tim revisits his earlier abandoned tease in proposing that the paint job is so bad it looks that it was "done with pen” (line 81), although this negative assessment occasioned through this criticism is not immediately affiliated with by Bryan (line 82). Melissa, on the other hand, reformulates her prior displayed acceptance of Bryan's evaluative stance with an oh-prefaced claim of having not noticed that the paint job was poor overall prior to Bryan pointing it out (line 85). According to Heritage (2002), this oh-prefacing constitutes a possible resource by means of which Melissa claims the "epistemic independence" of her stance compared to that proffered by Bryan in his sequentially first negative assessment. In other words, Melissa "conveys that the opinion that follows the oh-preface is independent of the 'here-and-now' of current experience and the prior speaker's evaluation" (Heritage, 2002: 201), by proffering "not noticing” at the time of purchase as an account for buying what appears to be a defective gift. The evaluation with which Melissa claims epistemic independence and thus disaffiliates from is the one that has been implied here by Bryan, namely, the negative assessment casting her person as someone who purchases presents that are defective and unsophisticated.

Bryan then subsequently offers a further negative assessment of the present, comparing it something that Joanna (a young child) would paint (line 86), the jocularity of which is recognised by Cindy through subsequent laughter (line 87). Melissa, however, repeats her claim of "not noticing” (line 88), thereby once again disaffiliating from Bryan's negative assessment of her person. In being prefaced with an explicit rejection of this stance (i.e. "no"), then, Melissa's response constitutes a prototypical "po-faced response" to the tease, where she "treat[s] something about the tease, despite its humour, as requiring a serious response" (Drew, 1987: 230).

Although she does not overtly display recognition of these negative assessments as "non-serious" teases on the part of Bryan (and Tim), her understanding that these teases are framed as jocular becomes apparent in later talk, which follows on from a subsequent continuation of this teasing sequence (data not shown), where she offers yet another account for buying the present, as seen in excerpt (3) below. Here, she claims she "thought it was a joke" (at the time of purchase) (line 108), and subsequently laughs (line 111), which initiates the close of this teasing sequence.

(3) GCSAusE03: 2:25

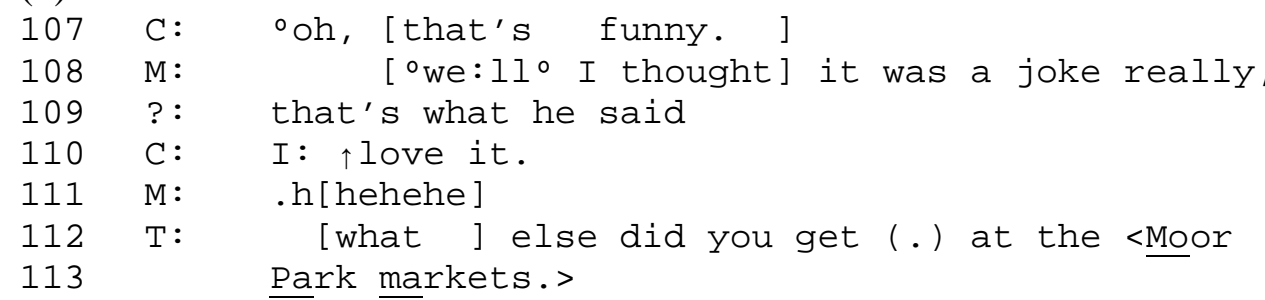


In other words, Melissa offers yet another defensive account in an attempt to negate or neutralise the prior negative assessments of her person as someone who buys defective gifts, but also at the same time displays recognition of the non-serious tenor of this teasing sequence. In this latter part of the sequence (in excerpt [1] as well as [2]), Melissa holds Bryan (and Tim) accountable for these teases, by disaffiliating with their implied negative assessment of her person, while at the same time affiliating with their negative assessment of the gift itself. Cindy, on the other hand, ultimately disaffiliates with their negative assessment of the gift (line 110), and thus disaffiliates with their negative assessment of the target's person (i.e. Melissa), and so in excerpt (3) takes the reception footing of accounter alongside Melissa.

What is critical to consider in relation to the participation footings in this particular excerpt, however, is the responses of Tim and Cindy as opposed to Melissa to these ostensibly "non-serious" or jocular negative assessments, which are directed at Melissa's person as both the direct addressee as well target of the teases. On the one hand, Tim and Cindy, who are treated as side participants to Bryan's teasing utterances, align with the mockery as jocular through elaborating on the teases (Tim) or through laughter (Cindy). In "collectivising” this tease amongst the other side participants (Laforest, 2009), its (illocutionary) force is arguably potentially increased. This also has the effect of increasing the degree of affiliation between the primary initiator of the teasing sequence (Bryan) and the side participants (Tim and Cindy) (Dobs and Garcés-Conejos Blitvich, forthcoming). On the other hand, Melissa's po-faced response, while evidently recognising the non-serious or jocular nature of the teases and thus aligning with the jocular mockery as an ongoing social action in this interaction, nevertheless disaffiliates with the negative assessments of her person occasioned by those instances of jocular mockery. In other words, the side participants affiliate with these negative assessments of Melissa, while the direct addressee/target here disaffiliates with them. Thus, while it appears that jocular mockery has indeed been interactionally achieved here amongst these participants (Haugh, 2010b), the interpersonal implications of it are evaluated differently by the participants.

From the perspective of those participants affiliating with the interpersonal evaluations of Melissa's person occasioned by this jocular mockery (i.e., Tim, Bryan and Cindy, at least initially), the negative assessments are most likely evaluated as "not impolite"; in other words, the evaluative social action arguably occasions evaluations of mock impoliteness (Haugh and Bousfield, 2012). However, from the perspective of the target and direct addressee (i.e., Melissa), who is disaffiliating with the negative assessments of her person, we can infer that she may be in fact be evaluating it as "not polite". Nevertheless, because the negative assessments are framed as "jocular", there is a strong normative expectation at play among these Anglo-Australians that she will "not take herself too seriously" (Goddard, 2009), and so she appears to resort in the end to treating the present as "a joke", thereby both affiliating with the (potentially) positive evaluations of their relational connection (i.e., as family members between whom jocular mockery is allowable and indeed even "enjoyed" by at least some), as well as initiating the close of this teasing sequence (line 108, in except [3] above). Notably, at this point, Cindy offers the only positive assessment of the gift in this entire conversation ("I love it" in line 110), thereby rejecting Melissa's prior negative assessment of the gift, and the potentially selfdeprecatory implications of that assessment (Pomerantz, 1984). This provides evidence that at least one of the participants is aware that the jocular mockery could have been evaluated as "not polite" by Melissa, in that Cindy appears to be ultimately 
disaffiliating from the negative assessments occasioned by Bryan's and Tim's teases by offering a reformulated positive assessment of the gift. In that sense, it also constitutes an attempt to compensate for or mitigate the threats to Melissa's person that the negative assessments engendered, a social action that is itself open to evaluation as "polite".

It appears, then, that such assessments, and the evaluations of im/politeness they occasion, arise in interplay with the ongoing relational histories of these interactants (Arundale, 2010a, 2010b; Clark, 2011; Haugh, 2007b; Mills, 2003; Sifianou, 2012; Spencer-Oatey, 2011). It also indicates that evaluations of im/politeness (specifically "not polite" and "mock impolite” here) draw implicitly from an underlying moral order (Garfinkel, 1967), namely, a set of (inter)subjective background expectancies through which participants interpret and evaluate social actions/pragmatic meanings that is variably distributed across relational networks (Haugh, 2012a). Here the analysis has drawn specifically from moral dimensions of the epistemic order (Heritage, 2012; Stivers, Mondada and Steensig, 2011): first, through giving this present in the first place, Melissa has implicitly displayed knowledge of what she thinks the gift receivers (Cindy and Bryan) would want, like or need (Robles, 2012: 767), and second through the assessments themselves, by which of the speaker (specifically, the author) claims he or she has some degree of knowledge of the assessable (Pomerantz, 1984). It has also alluded to aspects of the deontic order in claiming the assessments occasion evaluations of "mock impoliteness", at least for Bryan, Tim, and initially Cindy, because the evaluation of something being "not impolite" here implicitly builds on the moral expectation that a gift-giver is "entitled" to receive positive assessments from the gift-receiver(s) and other side participants (Good and Beach, 2005; Robles, 2012). ${ }^{15}$ Finally, the participation order itself also becomes morally-loaded here because assessments in gift-giving contexts "construct and enact shared experiences and collective affect" (Robles, 2012: 757), but in this case, the participation order is co-constituted in such a way that a relational "alliance" against Melissa temporally arises, rather than the expected positive assessments being distributed across the gift-receivers (Cindy and Bryan) and the side-participant (Tim) to that gift-giving.

Thus, while an "insider" understanding of this moral order is often (implicitly) claimed by the analyst (cf. Bravo, 2008), it is becoming clear that this moral order should itself be a primary focus of analysis in studies of im/politeness (BargielaChiappini, 2003; Eelen, 2001; Watts, 2003; see also Kádár and Haugh, in press 2013). Further discussion of these issues lies outside of the scope of present analysis, however, where the main point to be noted is that the participants do not affiliate to the same degree with the negative assessments of Melissa's person that arise in the course of this interaction. In other words, the evaluations that arise here are not uniformly shared across them. The inherent variability of im/politeness evaluations is thus a function, in part, of the ways in which they are distributed across the various participation footings available to interactants in multi-party talk-in-interaction.

However, while multi-party conversations are an obvious place where numerous participant footings may arise, and thus where multiple understandings of $\mathrm{im} /$ politeness are likely to arise, even in interactions involving just two participants,

\footnotetext{
${ }^{15}$ Robles (2012), for instance, claims that in the normal course of things, “what 'everyone knows' is what everyone must pretend not to know - which is that gifts are socially and relationally loaded, that you cannot react badly to a gift even if it is undesirable, and that gifts must be assumed to have been selected in good faith, with positive intention, and aided by close knowledge of the recipient.” (p.774, original emphasis).
} 
the variable footings that these participants invoke can also be interactionally consequential. In the following excerpt, for instance, one of the interactants exploits participant footings in formulating a complainable (i.e., a potential complaint). Here the older sister, Bianca, is talking over dinner about wondering whether her boyfriend Barry had called while she was out that afternoon. The excerpt below thus constitutes a noticeable side sequence from the main project here (Jefferson, 1972), namely, a telling here on Bianca's part that she feels upset about Barry not calling her. The side sequence is initiated by Adriana's question about the whereabouts of the coke.

(4) ICE-AUS: S1A-007: 8:39

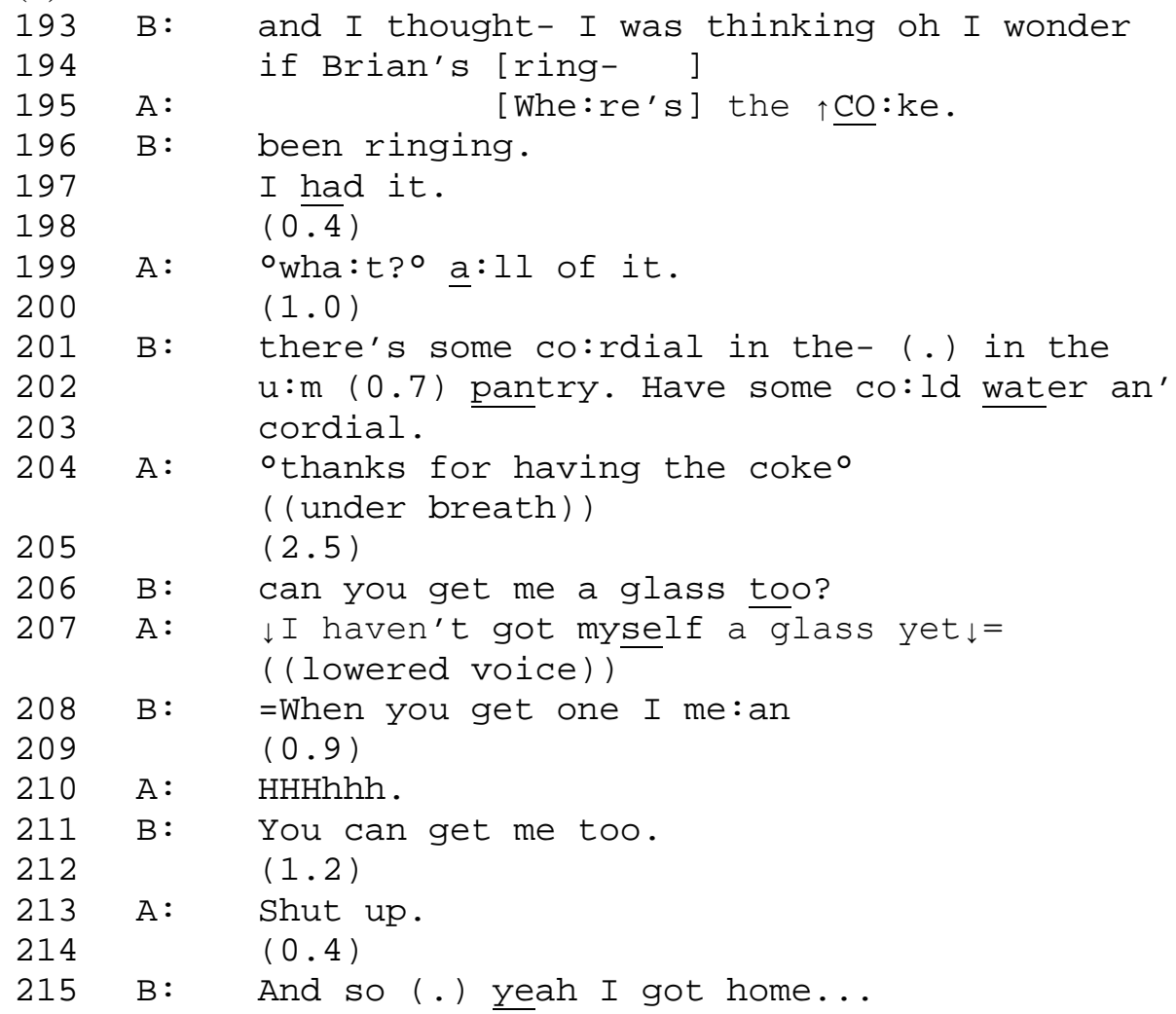

While formulated syntactically as an interrogative, Adriana's utterance in line 195 is Janus-faced in a manner similar to the use of why-interrogatives in soliciting accounts (Bolden and Robinson, 2011). On the one hand, it functions as a question seeking an explanation or account as to what has happened to the coke that Adriana evidently expected to find in the fridge, and so indexes an epistemic gap between the speaker (Adriana) and direct addressee (Bianca). On the other hand, it also indexes some "measure of epistemic access to the accountable event and [so] communicate[s] a stance that it does not accord with common sense and thus is possibly inappropriate or unwarranted" (Bolden and Robinson, 2011: 115). In other words, through reporting an 'unhappy incident', namely, the coke not being in the fridge (Pomerantz, 1978b), and seeking an account for that state of affairs, Adriana is also implying an accusation that Bianca may be the one responsible for this 'unhappy incident'. Robinson and Bolden (2010) argue that since account solicitations "positioned contiguously (i.e. immediately following) an accountable action" are dispreferred, the utterance here enacts a form "“aggravated disaffiliation' (relative to that enacted by withheld solicitations)” (p.519). Upon hearing Bianca admit that she finished off the coke (line 197), Adriana indexes a stance of "shocked surprise" with a faintly uttered "what" token, which here functions as a self-directed response cry (Goffman, 1978[1981]), 
followed by another utterance that is syntactically formulated as a polar question (line 199), but also carries a negative evaluative load in relation to Bianca's prior confession, similar to the above wh-interrogative in line 195. From this stance of "aggravated disaffiliation" it is apparent that Adriana has evaluated her sister's finishing off of the coke as an "impropriety" (Drew, 1998), specifically, in relation to her "entitlement" to have this respected as belonging to Adriana (cf. Curl and Drew, 2008; Spencer-Oatey, 2002), and it is in this sense that the evaluation invokes aspects of the deontic order. In this case, then, it is this evaluation of an impropriety on the part of Adriana which evidently occasions an evaluative social action (i.e. accusing or blaming).

This evaluative social action is, in turn, is open to evaluation by Bianca. However, Bianca does not orient to this stance of aggravated disaffiliation in her subsequent turn, but rather simply offers an alternative to drinking coke (lines 201203). This is followed, in turn, by an ironically formulated thanks, which here functions as a complaint (line 204), a move which is perhaps occasioned by Bianca's lack of an affiliative response to the prior expression of aggravated disaffiliation on Adriana's part. Adriana achieves a shift in speaker footing in detaching herself from commitment as principal for this thanking, and thereby implies a strongly negative evaluation of the alleged target of this thanks, which is hearable as sarcasm (Clift, 1999). While this has been characterised as a form of "mock politeness" in the literature (Culpeper, 1996), this particular example is somewhat more complex in regards to participation footings at play here. Consistent with Culpeper's (1996) view, the seemingly positive evaluations of persons and relationships protoptyically occasioned by thanking is incongruous with the stance of aggravated disaffiliation indexed by Adriana, thereby indicating that this "polite" thanks is not meant sincerely (hence the evaluative label "mock politeness"). However, Adriana is also ostensibly inviting others to share in this negative evaluation through this ironic thanking, given she dissociates herself from the footing of principal in relation to this thanking (Clift, 1999). The analytical puzzle here is that in being delivered in a markedly softly spoken manner, it remains ambiguous whether the audience meant to undertake this evaluation actually includes Bianca. On the one hand, the complaint is clearly directed at Bianca, with the implicit expectation that Bianca should affiliate with Adriana's "sense of the impropriety" in regards to Bianca's behaviour, namely, that "the complainable impropriety involves a kind of rudeness or offensiveness" (Drew, 1998: 303). On the other hand, in being delivered in the manner of "self-talk" (Goffman, [1978]1981), Bianca is not being treated as a direct addressee or even ratified side participant, but rather as a potential "overhearer”, or more specifically, a bystander. In other words, there is real ambiguity in terms of participation footings here whether Bianca can or should respond to this ironic thanking and complaint. From another perspective, this means Bianca has been granted agency by Adriana, through the formulation and delivery of this complainable, to orient to it from at least two different reception footings: either as a ratified addressee (where an affiliative response is preferred) or as an unratified bystander (where no particular response is expectable). In the subsequent turn, Bianca once again does not orient to this disaffiliative stance on the part of Adriana, but rather launches a request that Adriana get her some cordial as well (line 206). In this way, she treats herself as an unratified bystander who is not expected to align with the complaint nor affiliate with the negative assessment of her person that it occasions in this instance (Drew, 1998; Drew and Walker, 2009). In subsequent turns, while Adriana initially refuses to get Bianca a drink (line 207) she eventually relents (lines 210 and 213), and Bianca returns to the 
main project at hand, namely, the telling about her boyfriend not calling her (line 215).

It is clear, then, that while Adriana evaluates Bianca's prior actions as an impropriety, Bianca does not appear herself to affiliate with that stance. In other words, she evidently does not evaluate her own prior behaviour as an impropriety in the course of this interaction. There is also no evidence to suggest that she regards Adriana's negative assessments of her behaviour as improper or out of line either. Instead, she appears to take the footing of a bystander, which is afforded by Adriana's delivery of ironic thanks, by not orienting to Adriana's evident upgrading of a stance of aggravated disaffiliation (progressively from lines 195 to 199 through to 204). Thus, while Adriana's evaluations of Bianca's prior actions become progressively more aggravated, Bianca does not affiliate with this stance. In other words, not only are there differences in evaluations of im/politeness distributed across their respective participation footings, there are also cumulative differences between these two individuals as this interaction progresses (cf. Mills, 2003: 136).

These differences reflect the way in which the moral order itself, here deontic aspects of the moral order in particular, are invoked by Adriana, but not oriented to or recognised by Bianca. While Adriana invokes a particular entitlement here, namely, the right to "finish off the coke", and the lack of entitlement on Bianca's part to do so unless given "permission" by Adriana, and it is these differential entitlements which ground Adriana's evaluation of Bianca's prior conduct as an "impropriety”, these entitlements are not recognised by Bianca in her subsequent responses. In this way, we can see that aspects of the moral order can be invoked by one participant in order to ground an evaluation as one pertaining to matters of propriety, etiquette, appropriateness, and, of course, im/politeness, rather than being an idiosyncratic evaluation, for particular locally situated purposes (i.e. to formulate a complaint about the impropriety of "finishing off the coke"), and yet the invoking of the moral order is not necessarily recognised in the same way as another participant, once again in all likelihood for particular locally situated purposes (i.e. to downplay the seriousness of this complaint). This, in turn, reflects the way in which the moral order is ultimately co-constituted through interaction amongst members, rather than being a set of suprainteractional "norms" that are imposed by the analyst, or a set of normative "frames" or "conceptual typifications" located in the minds of individual participants through which they are able to "recognise" instances of im/politeness.

However, it is important to bear in mind at this point that these evaluations also arise relative to the relational history of these two interactants as sisters, between whom no doubt disputes about food and drink have previously arisen. The fact that Adriana's negative assessments directed at Bianca's “impropriety” do not occasion subsequent negative assessments from Bianca directed at Adriana, nor do they constitute any more than a side sequence to Bianca's overall project of storytelling, suggests that such negative evaluations are part and parcel of the constituting of their relationship over time. It has been argued that personal identities and relational histories are potentially constitutive of im/politeness evaluations because they can, as Sifianou (2012) points out, "affect the development and outcome of any interaction”, and thus "such differences affect judgements relating to politeness or impoliteness" (p.1558). In other words, we need to go beyond an examination of situated talk-ininteraction to also consider relational histories and participant identities in analysing $\mathrm{im} /$ politeness in interaction. It should be emphasised that a focus on the participation order in examining evaluations in interaction does not preclude any such broader considerations in the analysis of im/politeness evaluations. 


\section{Evaluations of im/politeness, “audiences" and the analyst}

It has recently been argued that audiences of film or television interactions, and mediated interactions more generally, are akin to meta-recipients engaging in a distinct meta-level of communication (Dynel, 2011b, 2012; Garcés-Conejos Blitvich, Lorenzo-Dus and Bou-Franch, 2010). While they participate as overhearers of the film or television interactions, for instance, they also have recognised reception footings that go beyond those of co-present overhearers (e.g. audiences may have different understandings of talk and conduct, and thus may have evaluations of $\mathrm{im} /$ politeness that are distinct from those of the characters due to different levels of background knowledge). The im/politeness evaluations of meta-recipients thus constitute a distinct layer for analysis in im/politeness research. In some cases, the evaluations of meta-recipients may in fact be much more consequential in the everyday world than those of the initially co-present recipients (Haugh, 2008, 2010a). Participation footings should thus be further embedded in a further meta-level of reception footings in examining mediated interactions (Kádár and Haugh, in press 2013).

We can go further, however, in noting that the footing of the analyst is also generally synonymous with that of a meta-recipient (apart from instances where the analyst is also a participant), a point that should always be borne in mind in any examination of im/politeness evaluations in interaction (Haugh, 2007b, 2012b). It is only natural that the analyst, as a meta-recipient, will form his or her own interpretations and evaluations of the interpersonal import of social actions and pragmatic meanings that arise in a particular interaction (as in drawing upon these in presuming "insider" knowledge of the moral order underpinning such evaluations). What is required of the analyst, then, is reflexive awareness of one's footing as a meta-recipient relative to that of the participants, as well as reflexive awareness of one's understanding of aspects of the moral order that are invoked by participants in occasioning evaluations of im/politeness (see also Kádár and Haugh, in press 2013). In other words, we need to first appreciate that our understandings as analysts are akin to that of a meta-recipient, and thus we naturally form our own understandings of the social actions and meanings that arise in the interaction vis-à-vis im/politeness (although we need to distance ourselves from them) (cf. Watts, Ide and Ehlich, 1992), and second that we need to be reflexively aware of our own status as either "insiders" or "outsiders" to the locally instantiated moral order through which the participants themselves ground their evaluations of im/politeness.

Our task as analysts is thus to closely examine the ways in which the participants themselves display evaluations and responses to those evaluations of persons and relationships in interaction, and the ways in which they position themselves vis-à-vis the im/politeness evaluations that such social actions and meanings occasion. Our job is also to take more seriously the task of examining how aspects of the moral order are invoked by participants in order to ground their evaluations as evaluations of im/politeness rather than being idiosyncratic ones, and how the fabric of the moral order is co-constituted (and also challenged and changed) by participants across relational networks over time. In this paper, it has been suggested that systematic analysis of the moral order more broadly, and the participation order specifically, as they are instantiated moment-by-moment in interaction is a useful means of moving the analysis of im/politeness evaluations beyond a situation where the researcher's evaluations of im/politeness - in his or her 
footing as a meta-recipient - are inadvertently confounded with analysis, as well as for developing a much more finely nuanced account of just whose evaluation we are analysing, and the (moral) grounds on which such evaluations are made. It is in this sense, then, that we as im/politeness researchers should inevitably be focusing on understandings of im/politeness (Kádár and Haugh, in press 2013), rather than foregrounding any one particular understanding through categorising some talk or talk, albeit locally situated, as polite, impolite and so on. It is also in this sense that there is much for the analyst to do in im/politeness research that goes beyond simply reproducing the unreflective understandings of participants, since a great deal of the evaluative work that goes on in interaction is evidently not consciously recognised by, or even remains opaque, to participants themselves.

Finally, it is important to note that while the current analysis has drawn heavily from methods and research in ethnomethodological conversation analysis, including the use of relatively detailed transcripts of audio/visual recordings of spontaneous, natural-occuring interactions, this should not be taken to amount to the claim that this is the only way of effectively analysing im/politeness. Indeed, our understanding of the moral order vis-à-vis im/politeness, for one, is likely to benefit from other methods and approaches, in particular, those which explore the metapragmatics of im/politeness (Culpeper, 2011; Kádár and Haugh, in press 2013). However, one advantage of an ethnomethodological conversation analytic approach in analysing im/politeness as social practice is that it enables close and detailed analyses of participant understandings against the interpretative backdrop of a rapidly growing body of work that details interactional practices and competencies that participants themselves draw upon in interpreting social actions. Another advantage is that the level of detail in transcripts, albeit selective (Bucholtz, 2000), enables other researchers to not only inspect - and perhaps even critique - such analyses for themselves, but also to expand upon the data itself in other analytical directions. In this way, the data itself can enter into on-going debates about the theorisation of $\mathrm{im} /$ politeness as opposed to remaining primarily under the purview of the originating researcher.

\section{Concluding remarks}

In this paper, it has been proposed that im/politeness evaluations be conceptualised as social practices that are occasioned through particular social actions and pragmatic meanings in situated, talk-in-interaction. It has been argued, on the one hand, that particular social actions and pragmatic meanings can be evaluated as polite, impolite, mock impolite, mock polite and so on by participants vis-à-vis aspects of the moral order, and in this sense, constitute a social practice. It has been argued, on the other hand, that since particular social actions and pragmatic meanings can be understood as reflexively evaluative of persons, that social actions and pragmatic meanings themselves can be occasioned by evaluations of im/politeness, and it is also in this sense that im/politeness constitutes a social practice. In advocating that the analysis of $\mathrm{im} /$ politeness evaluations be grounded in the understandings of participants it has been further argued that the notion of participant itself needs to be more carefully theorised. Not only should we be careful that the analyst's evaluations are not masquerading as those of the participants, we also need to be aware of the multiple potential footings in which the participants' evaluations themselves may be grounded. An examination of im/politeness evaluations relative to the participation order indicates that these evaluations are distributed across multiple participation footings 
and are consequently variable and cumulative over interactional sequences. The analysis and theorisation of im/politeness thus needs to deal with such evaluations at the level of locally situated participation orders. However, it is important to acknowledge that the instantiation of participation orders in particular instances of talk-in-interaction inevitably draws from the broader relational histories of those interactants. Ultimately, then, scientific theorisation needs to deal with im/politeness not only at a local interactional level but also at the level of multiple interactions between participants across social or relational networks. However, in moving to examine im/politeness evaluations beyond particular instances of localised talk-ininteraction it is important to bear in mind the lessons that a close examination of such evaluations in talk-in-interaction offers. Indeed, without careful consideration of the implications of such analyses, we are in danger of losing sight of the fact that evaluations of im/politeness are prototypically grounded in some kind of localised talk-in-interaction.

\section{Transcription conventions}

[ ]

$(0.5)$

(.)

:

$-$

.

?

,

$=$

\section{underlining}

CAPS

$\circ \circ$

.hhh

Hhh

$\downarrow \uparrow$

$><$

$<>$

( ) overlapping speech

numbers in brackets indicate pause length

micropause

elongation of vowel or consonant sound

word cut-off

falling or final intonation

rising intonation

'continuing' intonation

latched utterances

contrastive stress or emphasis

markedly louder

markedly soft

in-breathing

out-breathing/laughter

sharp falling/rising intonation

talk is compressed or rushed

talk is markedly slowed or drawn out

blank space in parentheses indicates uncertainty about the transcription

\section{References}

Arundale, Robert. 1999. An alternative model and ideology of communication for an alternative to politeness theory. Pragmatics 9:119-154.

Arundale, Robert. 2006. Face as relational and interactional: a communication framework for research on face, facework, and politeness. Journal of Politeness Research 2:193-216.

Arundale, Robert. 2010a. Constituting face in conversation: face, facework and interactional achievement. Journal of Pragmatics 42:2078-2105.

Arundale, Robert. 2010b. Relating. In Interpersonal Pragmatics, eds. Miriam A Locher and Sage Lambert Graham, 137-165. Berlin: Mouton de Gruyter.

Arundale, Robert. this issue. Face, relating, and dialectics: a response to SpencerOatey.

Augoustinos, Martha, Walker, Iain, and Donaghue, Ngaire. 2006. Social Cognition. London: Sage. 
Bargiela-Chiappini, Francesca. 2003. Face and politeness: new (insights) for (old) concepts. Journal of Pragmatics 35:1453-1469.

Beach, Wayne. 1995. Conversation analysis: "okay” as a clue for understanding consequentiality. In The Consequentiality of Conversation, ed. Stuart J Sigman, 259-289. Hillsdale, NJ: Lawrence Erlbaum.

Béal, Christine, and Mullan, Kerry. forthcoming. Issues in conversational humour from a cross-cultural perspective: comparing French and Australian corpora. In Cross-culturally Speaking, Speaking Cross-culturally, eds. Christine Béal, Kerry Mullan and Bert Peeters. Newcastle-upon-Tyne: Cambridge Scholars Press.

Bolden, Galina B, and Robinson, Jeffrey D. 2011. Soliciting accounts with whyinterrogatives in conversation. Journal of Communication 61:94-119.

Bourdieu, Pierre. 1977. Outline of a Theory of Practice. Cambridge: Cambridge University Press.

Bourdieu, Pierre. 1990. The logic of practice. Cambridge: Polity Press.

Bousfield, Derek. 2008. Impoliteness in Interaction. Amsterdam: John Benjamins.

Bousfield, Derek. 2010. Researching impoliteness and rudeness: issues and definitions. In Interpersonal Pragmatics, eds. Miriam A Locher and Sage L Graham, 101-134. Berlin: Mouton de Gruyter.

Bravo, Diana. 2008. (Im)politeness in Spanish-speaking socio-cultural contexts: Introduction. Pragmatics 18:563-576.

Brown, Penelope and Levinson, Stephen. 1987. Politeness: Some Universals in Language Usage. Cambridge: Cambridge University Press.

Bucholtz, Mary. 2000. The politics of transcription. Journal of Pragmatics 32:143965.

Clark, Jodi. 2011. Relational work in a sporting community of practice. In Situated Politeness, eds. Bethan Davies, Michael Haugh and Andrew John Merrison, 88-107. London: Continuum.

Clift, Rebecca. 1999. Irony in conversation. Language in Society 28:523-553.

Culpeper, Jonathan. 1996. Towards an anatomy of impoliteness. Journal of Pragmatics 25:349-367.

Culpeper, Jonathan. 2005. Impoliteness and entertainment in the television quiz show: the weakest link. Journal of Politeness Research 1:35-72.

Culpeper, Jonathan. 2011a. Impoliteness: Using Language to Cause Offence. Cambridge: Cambridge University Press.

Curl, Traci S, and Drew, Paul. 2008. Contingency and action: a comparison of two forms of requesting. Research on Language and Social Interaction 41:129-153.

Dobs, Abby and Blitvich, Pilar Garcés-Conejos. forthcoming. Impoliteness in polylogal interaction: accounting for face-threat witnesses’ responses. Journal of Pragmatics.

Drew, Paul. 1987. Po-faced receipts of teases. Linguistics 25:219-253.

Drew, Paul. 1998. Complaints about transgressions and misconduct. Research on Language and Social Interaction 31:295-325.

Drew, Paul, and Walker, Traci. 2009. Going too far: Complaining, escalating and dissafiliation. Journal of Pragmatics 41:2400-2414.

Durkheim, Émile. [1912]1915. The Elementary Forms of the Religious Life (translated by Joseph Ward Swain). London: George Allen \& Unwin.

Dynel, Marta. 2011a. 'You talking to me?' The viewer as a ratified listener to film discourse. Journal of Pragmatics 43:1628-1644. 
Dynel, Marta. 2011b. Revisiting Goffman's postulates on participant statuses in verbal interaction. Language and Linguistic Compass 5:454-465.

Dynel, Marta. 2012. Setting our House in order: the workings of impoliteness in multi-party film discourse. Journal of Politeness Research 8:161-194.

Eelen, Gino. 2001. A Critique of Politeness Theories. Manchester: St. Jerome.

Fairclough, Norman. 2003. Analysing discourse: Textual analysis for social research. London: Routledge.

Foucault, Michel. 1972. The Archaeology of Knowledge. London: Tavistock.

Garcés-Conejos Blitvich, Pilar. 2010. A genre approach to the study of im-politeness. International Review of Pragmatics 2:46-94.

Garcés-Conejos Blitvich, Pilar. 2013. Introduction: Face, identity and politeness. Looking backward, moving forward: from Goffman to practice theory. Journal of Politeness Research 9:1-33.

Garcés-Conejos Blitvich, Pilar, Lorenzo-Dus, Nuria and Bou-Franch, Patricia. 2010. A genre approach to impoliteness in a Spanish television talk show: evidence from corpus-based analysis, questionnnaires and focus groups. Intercultural Pragmatics 7:689-723.

Garfinkel, Harold. 1956. Conditions of successful degradation ceremonies. American Journal of Sociology 61:420-24.

Garfinkel, Harold. [1964]1967. Studies of the routine grounds of everyday activitie. Social Problems 11.225-50. Republished in 1967, 35-75.

Garfinkel, Harold. 1967. Studies in Ethnomethodology. Englewood Cliffs, NJ: Prentice-Hall.

Garfinkel, Harold. 2002. Ethnomethodology's Program. Working Out Durkheim’s Aphorism Lanham, MA: Rowman \& Littlefield.

Giddens, Anthony. 1984. The Constitution of Society. Outline of the Theory of Structuration. Cambridge: Polity Press.

Goddard, Cliff. 2009. Not taking yourself too seriously in Australian English: semantic explications, cultural scripts, corpus evidence. Intercultural Pragmatics 6:29-53.

Goffman, Erving. 1967. Interaction Ritual. Essays on Face-to-face Behavior. New York: Pantheon Books.

Goffman, Erving. 1978[1981]. Response cries. Language 54:787-815. Republished 1981, 78-123.

Goffman, Erving. 1979[1981]. Footing. Semiotica 25:1-29. Republished 1981, 124159.

Goffman, Erving. 1981. Forms of Talk. Philadelphia: University of Pennsylvania Press.

Good, Jeffrey and Beach, Wayne. 2005. Opening up gift-openings: birthday parties as situated activity systems. Text 25:565-93.

Goodwin, Charles, and Goodwin, Marjorie Harness. 1987. Concurrent operations on talk: notes on the interactive organization of assessments. IPrA Papers in Pragmatics 1:1-54.

Goodwin, Charles, and Goodwin, Marjorie Harness. 2004. Participation. In A Companion to Linguistic Anthropology, ed. Alessandro Duranti, 222-244. Malden, MA: Blackwell.

Grice, Paul. 1978. Further notes on logic and conversation. In Syntax and Semantics Volume 9. Pragmatics, ed. P. Cole, 113-127. NY: Academic Press.

Hanks, William. 2005. Pierre Bourdieu and the practices of language. Annual Review of Anthropology 34:67-83. 
Hatfield, Hunter, and Hahn, Jee-Won. 2011. What Korean apologies require of politeness theory. Journal of Pragmatics 43:1303-1317.

Haugh, Michael. 2007a. The co-constitution of politeness implicature in conversation. Journal of Pragmatics 39:84-110.

Haugh, Michael. 2007b. The discursive challenge to politeness theory: an interactional alternative. Journal of Politeness Research 3:295-317.

Haugh, Michael. 2008. Intention and diverging interpretings of implicature in the "uncovered meat" sermon. Intercultural Pragmatics 5.201-29.

Haugh, Michael. 2010a. When is an email really offensive? Argumentativity and variability in evaluations of impoliteness. Journal of Politeness Research 6:731.

Haugh, Michael. 2010b. Jocular mockery, (dis)affiliation, and face. Journal of Pragmatics 42:2106-2119.

Haugh, Michael. 2011. Epilogue: culture and norms in politeness research. In Politeness in East Asia, eds. Daniel Z Kádár and Sara Mills, 252-264. Cambridge: Cambridge University Press.

Haugh, Michael. 2012a. Conversational interaction. In The Cambridge Handbook of Pragmatics, eds. Keith Allan and Kasia M Jaszczolt, 251-273. Cambridge: Cambridge University Press.

Haugh, Michael. 2012b. Epilogue: The first-second order distinction in face and politeness research. Journal of Politeness Research 8:111-134.

Haugh, Michael. 2013a. Disentangling face, facework and im/politeness. Sociocultural Pragmatics 1:46-73.

Haugh, Michael. 2013b. Speaker meaning and accountability in interaction. Journal of Pragmatics 48:41-56.

Haugh, Michael. forthcoming. (Im)politeness Implicatures. Berlin: Mouton de Gruyter.

Haugh, Michael, and Bousfield, Derek. 2012. Mock impoliteness, jocular mockery and jocular abuse in Australian and British English. Journal of Pragmatics 44:1099-1114.

Haugh, Michael, Davies, Bethan, and Merrison, Andrew John. 2011. Situating politeness. In Situated Politeness, eds. Bethan Davies, Michael Haugh and Andrew John Merrison, 1-23. London: Continuum.

Haugh, Michael, and Jaszczolt, Kasia M. 2012. Speaker intentions and intentionality. In The Cambridge Handbook of Pragmatics, eds. Keith Allan and Kasia M Jaszczolt, 87-112. Cambridge: Cambridge University Press.

Heinemann, Trine. 2006. “Will you or can’t you?” Displaying entitlement in interrogative requests. Journal of Pragmatics 38:1081-104.

Heritage, John. 1984a. Garfinkel and Ethnomethodology. Cambridge: Polity Press.

Heritage, John. 1984b. A change of state token and aspects of its sequential placement. In Structures of Social Action, eds. Maxwell J Atkinson and John Heritage, 299-345. Cambridge: Cambridge University Press.

Heritage, John. 2002. Oh-prefaced responses to assessments. In The Language of Turn and Sequence, eds. Cecilia E Ford and Sandra A Thompson, 196-224. Oxford: Oxford University Press.

Heritage, John. 2012. Epistemics in action: action formation and territories of knowledge. Research on Language and Social Interaction 45:1-29.

Holmes, Janet, Marra, Meredith and Schnurr, Stephanie. 2008. Impoliteness and ethnicity: Maaori and Paakehaa discourse in New Zealand workplaces. Journal of Politeness Research 4:193-219. 
Housley, William and Fitzgerald, Richard. 2009. Membership categorisation, culture and norms in action. Discourse and Society 20:345-62.

Jefferson, Gail. 1972. Side sequences. In Studies in Social Interaction, ed. David Sudnow, 294-338. New York: The Free Press.

Jefferson, Gail. 2004. Glossary of transcript symbols with an introduction. In Conversation Analysis: Studies from the First Generation, ed. Gene Lerner, 13-23. Amsterdam: John Benjamins.

Kádár, Dániel Z, and Mills, Sara. 2011. Introduction. In Politeness in East Asia, eds. Dániel Z Kádár and Sara Mills, 1-17. Cambridge: Cambridge University Press.

Kádár, Dániel Z., and Haugh, Michael in press 2013. Understanding Politeness. Cambridge: Cambridge University Press.

Laforest, Marty. 2009. Complaining in front of a witness: aspects of blaming others for their behaviour in multi-party family interactions. Journal of Pragmatics 41:2452-2464.

Levinson, Stephen C. 1988. Putting linguistics on a proper footing: explorations in Goffman's concepts of participation. In Erving Goffman. Exploring the Interaction Order, eds. Paul Drew and Anthony Wootton, 161-227. Boston: Northeastern University Press.

Locher, Miriam. 2004. Power and Politeness in Action. Disagreements in Oral Communication. Berlin: Mouton de Gruyter.

Locher, Miriam. 2006. The discursive approach to polite behaviour: a response to Glick. Language in Society 35:733-735.

Locher, Miriam A. 2008. Relational work, politeness, and identity construction. In Handbook of Interpersonal Communication, eds. Gerd Antos and Eija Ventola, 509-540. Berlin: Mouton de Gruyter.

Locher, Miriam. 2012. Politeness research from past to future, with a special focus on the discursive approach. In New Perspectives on (Im)Politeness and Interpersonal Communication, eds. Lucía Fenandez-Amaya, Maria de la O. Hernandez-Lopez, Reyes Gomez Moron, Manuel Padilla Cruz, Manuel Mejias Borrero \& Marianna Relinque Barranca, 1-22. Newcastle upon Tyne: Cambridge Scholars Press.

Locher, Miriam, and Watts, Richard. 2005. Politeness theory and relational work. Journal of Politeness Research 1:9-34.

Locher, Miriam, and Watts, Richard. 2008. Relational work and impoliteness: negotiating norms of linguistic behaviour. In Impoliteness in Language, eds. Derek Bousfield and Miriam A Locher, 77-99. Berlin: Mouton de Gruyter.

LPRG [Linguistic Politeness Research Group]. 2011. Discursive Approaches to Politeness. Berlin: Mouton de Gruyter.

Mills, Sara. 2003. Gender and Politeness: Studies in Interactional Sociolinguistics. Cambridge: Cambridge University Press.

Mills, Sara. 2005. Gender and impoliteness. Journal of Politeness Research 1:263-80.

Mills, Sara. 2009. Impoliteness in a cultural context. Journal of Pragmatics 41:10471060.

Mills, Sara. 2011a. Communities of practice and politeness. In Situated Politeness, eds. Bethan Davies, Michael Haugh and Andrew John Merrison, 73-87. London: Continuum.

Mills, Sara. 2011b. Discursive approaches to politeness and impoliteness. In Discursive Approaches to Politeness, ed. by Linguistic Politeness Research Group, 19-56 . Berlin: Mouton de Gruyter. 
Ortner, Sherry. 2006. Anthropology and Social Theory: Culture, Power, and the Acting Subject. Durham, NC: Duke University Press.

Pennycook, Alastair. 2010. Language as local practice. London: Routledge.

Pomerantz, Anita. 1978a. Compliment responses: notes on the cooperation of multiple constraints. In Studies in the Organization of Conversational Interaction, ed. Jim Schenkein, 79-112. New York: Academic Press.

Pomerantz, Anita. 1978b. Attributions of responsibility: blamings. Sociology 12:115121.

Pomerantz, Anita. 1984. Agreeing and disagreeing with assessments: some features of preferred/dispreferred turn shapes. In Structures of Social Action. Studies in Conversation Analysis, eds. J. Maxwell Atkinson and John Heritage, 57-101. Cambridge: Cambridge University Press.

Pomerantz, Anita. 1988. Offering a candidate answer: an information seeking strategy. Communication Monographs 55:360-73.

Potter, Jonathan. 1998. Discursive social psychology: from attitudes to evaluative practices. European Review of Social Psychology 9:233-266.

Rawls, Anne. 2003. Orders of interaction and intelligibility: Intersections between Goffman and Garfinkel by way of Durkheim. In Goffman’s Legacy, ed. A. Javier Treviño, 216-53. Lanham, MA: Rowman \& Littlefield.

Reckwitz, Andreas. 2002. Toward a theory of social practice. European Journal of Social Theory 5:243-63.

Robinson, Jeffrey D, and Bolden, Galina B. 2010. Preference organization of sequence-initiating actions: the case of explicit account solicitations. Discourse Studies 12:501-533.

Robles, Jessica. 2012. Troubles with assessments in gifting occasions. Discourse Studies 14:753-77.

Rouse, Joseph. 2001. Two concepts of practices. In The Practice Turn in Contemporary Theory, eds. Theodore Schatzki, Karin Knorr Cetina and Eike von Savigny, 198-208. London: Routledge.

Ruhi, Sukriye. 2008. Intentionality, communicative intentions and the implication of politeness. Intercultural Pragmatics 5.

Samra-Fredericks, Dalvir. 2010. Ethnomethodology and the moral accountability of interaction: navigating the conceptual terrain of 'face' and face-work. Journal of Pragmatics 42:2147-57.

Schatzki, Theodore. 1996. Social practices: A Wittgensteinian approach to human activity and the social. Cambridge: Cambridge University Press.

Schatzki, Theodore. 2001. Introduction: Practice theory. In The Practice Turn in Contemporary Theory, eds. Theodore Schatzki, Karin Knorr Cetina and Eike von Savigny, 1-14. London: Routledge.

Schatzki, Theodore, Knorr Cetina, Karin and von Savigny, Eike (eds.) 2001. The Practice Turn in Contemporary Theory. London: Routledge.

Schegloff, Emanuel. 1995. Discourse as interactional achievement III: the omnirelevance of action. Research on Language and Social Interaction 28:185-211.

Schegloff, Emanuel. 2007. Sequence Organization in Interaction. Cambridge: Cambridge University Press.

Sidnell, Jack. 2012. “Who knows best?” Evidentiality and epistemic asymmetry in conversation. Pragmatics and Society 3:294-320.

Sifianou, Maria. 2012. Disagreements, face and politeness. Journal of Pragmatics 44:1554-1564. 
Spencer-Oatey, Helen. [2000]2008. Face, (im)politeness and rapport. In Culturally Speaking. Culture, Communication and Politeness Theory ( $2^{\text {nd }}$ edn), ed. Helen Spencer-Oatey, 11-47. London: Continuum.

Spencer-Oatey, Helen. 2002. Managing rapport in talk: using rapport sensitive incidents to explore the motivational concerns underlying the management of relations. Journal of Pragmatics 34:529-545.

Spencer-Oatey, Helen. 2005. (Im)Politeness, face and perceptions of rapport: unpackaging their bases and interrelationships. Journal of Politeness Research 1:95-120.

Spencer-Oatey, Helen. 2007. Theories of identity and the analysis of face. Journal of Pragmatics 39:639-656.

Spencer-Oatey, Helen. this issue. Relating at work: facets, dialectics and face.

Spencer-Oatey, Helen. 2011. Conceptualising the 'relational' in pragmatics: insights from metapragmatic emotion and (im)politeness comments. Journal of Pragmatics 43:3565-3578.

Stevanovic, Melisa and Peräkylä, Anssi. 2012. Deontic authority in interaction: the right to announce, propose, and decide. Research on Language and Social Interaction 45:297-321.

Stivers, Tanya. 2008. Stance, alignment, and affiliation during storytelling: when nodding is a token of affiliation. Research on Language and Social Interaction 41:31-57.

Stivers, Tanya. 2010. An overview of the question-response system in American English conversation. Journal of Pragmatics 42:2772-2781.

Stivers, Tanya. 2011. Morality and question design: “of course” as contesting a presupposition of askability. In The Morality of Knowledge in Conversation, eds. Tanya Stivers, Lorenza Mondada and Jakob Steensig, 82-106. Cambridge: Cambridge University Press.

Stivers, Tanya, Mondada, Lorenza, and Steensig, Jakob. 2011. Knowledge, morality and affiliation in social interaction. In The Morality of Knowledge in Conversation, eds. Tanya Stivers, Lorenza Mondada and Jakob Steensig, 3-24. Cambridge: Cambridge University Press.

Tannen, Deborah. 1993. What's in a frame?: surface evidence for underlying expectations. In Framing in Discourse, ed. Deborah Tannen, 14-56. Oxford: Oxford University Press.

Terkourafi, Marina. 2005. Beyond the micro-level in politeness research. Journal of Politeness Research 1:237-262.

Terkourafi, Marina. 2008. Toward a unified theory of politeness, impoliteness, and rudeness. In Impoliteness in Language., eds. Derek Bousfield and Miriam Locher, 45-74. Berlin: Mouton de Gruyter.

Verschueren, Jef. 1999. Understanding Pragmatics. London: Arnold.

Watts, Richard. 1999. Language and politeness in early eighteenth century Britain. Pragmatics 9:5-20.

Watts, Richard. 2003. Politeness. Cambridge: Cambridge University Press.

Watts, Richard, Ide, Sachiko and Ehlich, Konrad. 1992. Introduction. In Politeness in Language: Studies in its History, Theory and Practice, eds. Richard Watts, Sachiko Ide and Konrad Ehlich, 1-17. Berlin: Mouton de Gruyter.

Wilson, Thomas P. 2012. Classic ethnomethodology, the radical program, and conversation analysis. In Interaction and Everyday Life, eds. Hisashi Nasu and Frances Chaput Waksler, 207-38. Lanham, MA: Lexington. 
Xie, Chaoqun. 2008. (Im)politeness. Toward an evaluative and embodied approach. Pragmatics and Cognition 16:151-175 
Figure 1: Interpersonal evaluations as social practice

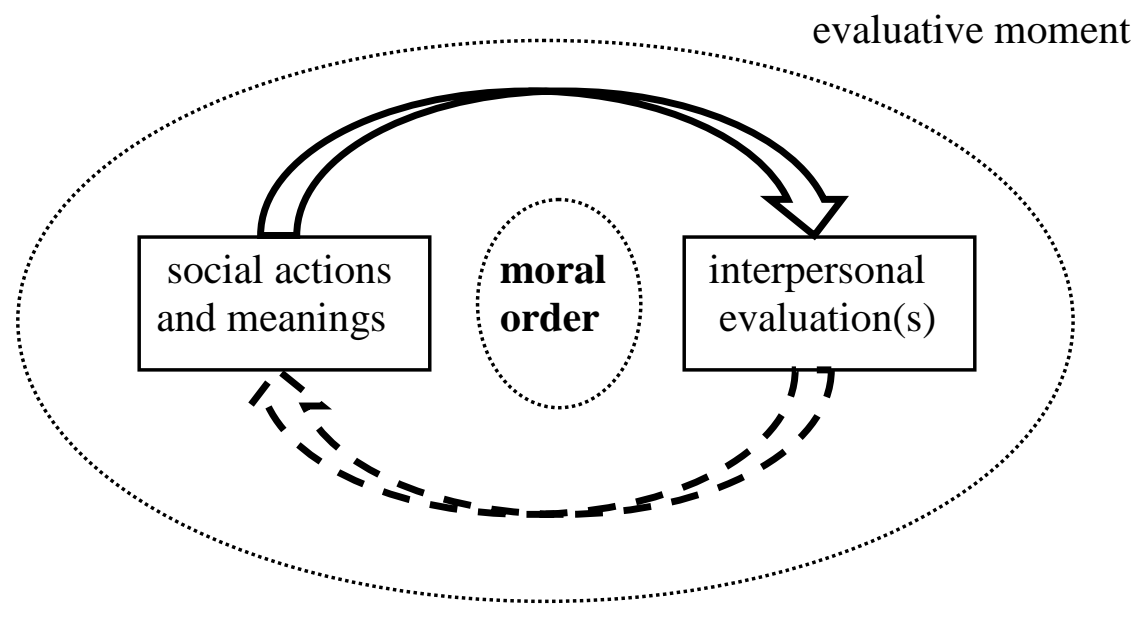


Figure 2: Types of participation footings

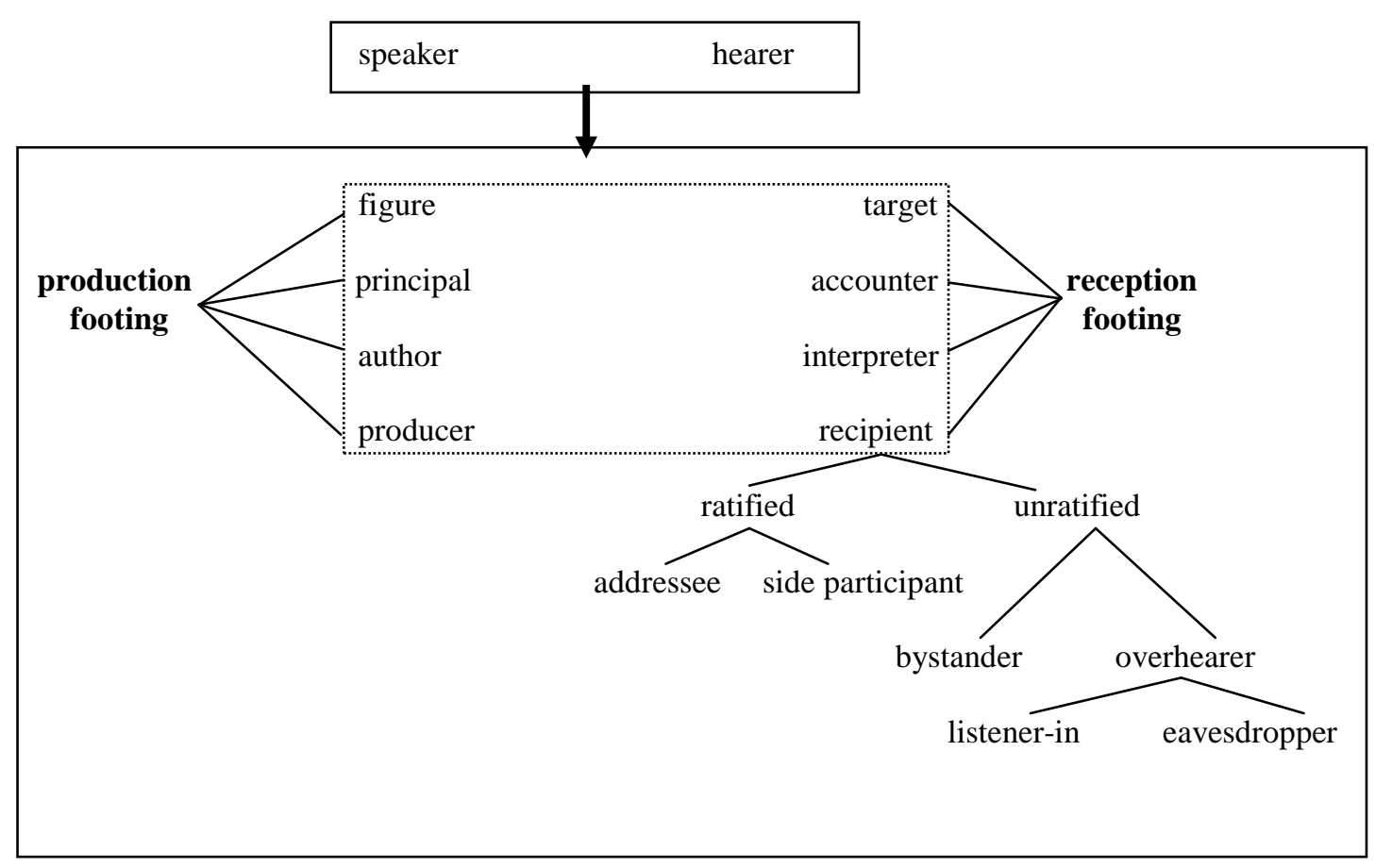

